\title{
Ficção japonesa em prosa publicada no Brasil
}

\author{
Elisa Figueira de Souza Corrêa*
}

Este texto é uma breve apresentação da pesquisa "Fiç̧ão japonesa em prosa publicada no Brasil", na qual se buscou identificar todas as obras de ficção em prosa da literatura japonesa publicadas no Brasil (em português), até 2020.

\section{Apresentação geral da pesquisa}

Quando se fala em literatura japonesa no Brasil, a chance de que o grande público tenha lido ou ouvido falar de mais do que de um ou dois autores é pequena. Mesmo entre os estudantes do curso de Letras Português/Japonês ${ }^{1}$, vejo que poucos já se debruçaram sobre essa literatura e, por vezes, caso sintam essa vontade, têm dificuldade de saber o que existe publicado em português - seja para lerem por prazer ou para alguma pesquisa acadêmica.

Nesse sentido, pareceu-me relevante investigar de forma exaustiva obras publicadas no Brasil (até 2020), não apenas como uma forma de auxiliar alunos e demais pesquisadores da área a saberem o que já existe disponível no país, mas como um incentivo a diversas possibilidades de pesquisa sobre, por exemplo, a história da tradução japonês-português no

\footnotetext{
${ }^{*}$ UERJ

${ }^{1}$ Existem nove universidades brasileiras onde é possível cursar essa graduação: Universidade Cruzeiro do Sul, Universidade de Brasília (UnB), Universidade de São Paulo (USP), Universidade do Estado do Rio de Janeiro (UERJ), Universidade Estadual Paulista Júlio de Mesquita Filho (UNESP), Universidade Federal do Amazonas (UFAM), Universidade Federal do Paraná (UFPR), Universidade Federal do Rio de Janeiro (UFRJ), Universidade Federal do Rio Grande do Sul (UFRGS).
} 
país, sobre a evolução do mercado editorial nessa área e, naturalmente, sobre os autores/estilos selecionados para serem publicados no Brasil.

Na delimitação do escopo da pesquisa, estabeleceu-se o seguinte recorte: apenas ficção em prosa de autores japoneses; apenas obras publicadas no Brasil; apenas obras traduzidas para o português. Decidiu-se por excluir, então, tanto traduções de outros países lusófonos, quanto obras publicadas em japonês no Brasil; assim como quaisquer obras escritas por autores brasileiros, americanos etc., ainda que fossem adaptações de texto original japonês. Note-se ainda que nem todas as obras indicam se a tradução foi direta ou indireta, portanto este ponto não foi extensivamente analisado nesta pesquisa, embora saibamos ser de grande importância dentro dos Estudos da Tradução. Seria preciso investigar mais sobre alguns tradutores para saber se tem ou se tinham ou não proficiência na língua japonesa.

Os resultados da pesquisa foram organizados em dois quadros, no entanto, nesta apresentação, gostaríamos de comentar alguns pontos, a saber: (i) a metodologia de pesquisa; (ii) a forma de contagem das edições; (iii) contribuições previstas. Por fim, tecemos algumas considerações finais.

Admite-se que, obviamente, a natureza desta pesquisa não permite mais que uma conclusão temporária, na medida em que a publicação de obras japonesas no país é contínua e, aliás, vem crescendo bastante nas últimas duas décadas. Ainda assim, se hoje já não foi fácil a identificação das primeiras traduções nacionais, à medida que os anos se passam tão mais difícil se faria essa missão.

Em suma, os dois quadros produzidos durante esta pesquisa trazem a apresentação de resultados com vistas a auxiliar e motivar outros pesquisadores e estudantes de áreas como estudos de Literatura Japonesa, Literatura Comparada e Estudos da Tradução.

\section{Metodologia de pesquisa}

A pesquisa das obras foi feita, mormente, na Internet ao longo dos últimos três anos. De fato, é possível encontrar pela Internet algumas listas, geralmente em blogs, sobre as obras japonesas publicadas no Brasil2. Uma

\footnotetext{
2 Alguns exemplos a título de ilustração: “Literatura japonesa publicada no Brasil" (http://www.culturajaponesa.com.br/index.php/idioma/literatura/literatura-japonesa-publicada-no-
} 
olhada rápida, entretanto, revela ao leitor mais experiente não se tratarem nunca de listas exaustivas. Ou, por vezes, trata-se de listas que contêm vários gêneros literários, e não apenas ficção em prosa, como a lista que se propôs estabelecer. Por fim, todas as listas inicialmente encontradas em blogs eram repetitivas no que é mais recente e incompletas em relação a períodos mais remotos, razão pelas quais não serviram de base para esta pesquisa.

Além disso, a escolha do recorte "ficção em prosa" deveu-se não apenas por ser o gênero mais abundante, como também o que pareceu ter um maior apelo imediato para o público leitor em geral e para os estudantes e pesquisadores de Letras, em particular, por ser geralmente o preferido entre os diversos gêneros e contar com nomes já mais conhecidos do grande público.

O mecanismo mais útil, crucial para esta pesquisa, foi a tecnologia para sugestão de compras dos websites de livrarias e dos próprios navegadores e mecanismos de busca na Internet, de modo que a grande maioria dos livros, esgotados ou não, pôde ser identificada em visitas a sebos e livrarias online e a websites de editoras. É importante destacar, conforme notou um dos pareceristas deste texto, que esse tipo de tecnologia não é, porém, completo e tampouco exaustivo. Segundo este parecerista, os mecanismos de sugestão da Internet funcionam com base nos pixels que monitoram a atividade do usuário para fazerem sugestões pontuais, e nunca totais. Sem dúvida, apenas a busca persistente em diferentes websites, juntamente à visita a acervos de bibliotecas e lojas físicas, ao longo desses três anos, fez com que pudéssemos crer ter concluído a tarefa.

Como exemplo, pode-se citar precisamente o caso de $A$ imagem de bronze, de Yoshio Nagayo (『青銅の基督』・長与善郎), o livro mais antigo publicado no país segundo as investigações. Esse livro foi encontrado num sebo de rua, por acaso - isto é, sem nunca ter, até aí, aparecido em nenhuma das pesquisas pela Internet. Trata-se de obra publicada em 1941 pelos Irmãos Pongetti, com tradução de Zenaide Andréa.

brasil/); "As 20 obras mais importantes da literatura japonesa" (https://www.mundodek.com/2017/02/as-20-obras-mais-importantes-da.html); “Literatura japonesa e seus 10 livros essenciais" (https://blog.estantevirtual.com.br/2016/03/31/literatura-japonesa-e-seus-10livros-essenciais/). 
Outras fontes valiosas foram os trabalhos de Fabio Kato (2006) e Andrei Cunha (2015), que identificaram mais uma obra que escapara da pesquisa pela Internet: a tradução de Rua sem sol, de Sunao Tokunaga (『太 陽のない街』 - 徳永直) ${ }^{3}$, publicada em 1945 pela Brasiliense, e que diversos pesquisadores pensavam ser a mais antiga até hoje (KATO, 2006; CUNHA, 2015).

Para a determinação da data de publicação, quando não discriminada na própria obra, contou-se com o acervo da Hemeroteca Digital, da Biblioteca Nacional. Graças a esta hemeroteca, foi possível determinar a data de publicação de diversas obras, como a de Nagayo supracitada. Observe-se que, segundo a reportagem de página inteira, "Cinema japonês" (A SCENA MUDA, 1941, p. 27), a versão brasileira de $A$ imagem de bronze é creditada, inclusive, como "a primeira tradução em uma língua ocidental [desta obra] e será também o primeiro romance japonês editado nas Américas" (A SCENA MUDA, 1941, p. 27).

Recorte da reportagem da revista A Scena Muda, de 18 de março de 1941:

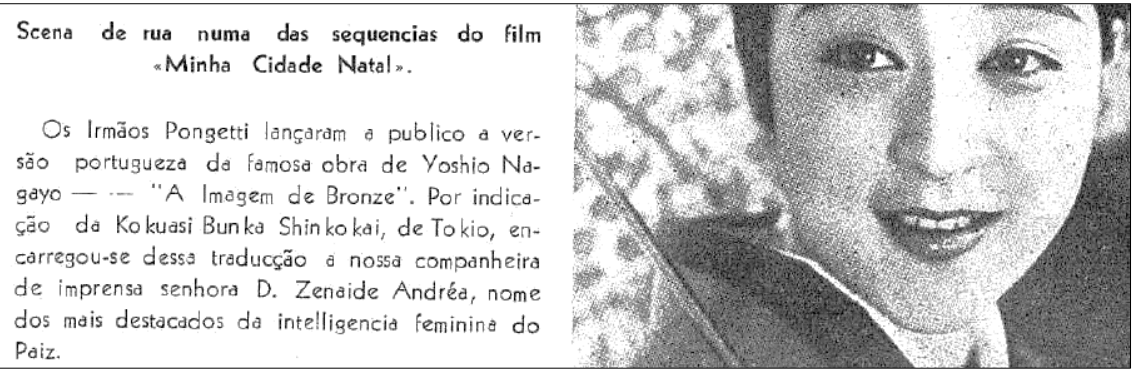

\section{Sobre a contagem das edições}

Os quadros de dados estão numerados para que se tenha mais clareza de quantas obras foram publicadas. A princípio, a ideia da pesquisa era identificar não apenas as obras japonesas traduzidas, mas também diferentes traduções de uma mesma obra no país. Rapidamente descobriu-se, porém, que um grande número de obras foi lançado mais de uma vez (muitas vezes

\footnotetext{
${ }^{3}$ A romanização do nome do autor aparece, erroneamente, como "Naoshi" Tokunaga, em vez de "Sunao" Tokunaga. Segundo Cunha (2015, p. 60, nota de rodapé n. 8), esse erro pode ter derivado da versão francesa ou alemã, que, possivelmente, serviu de base para a tradução brasileira.
} 
na mesma tradução), fosse por editoras diferentes, fosse pela mesma editora com alguns adendos ou revisões.

Percebeu-se por aí também que, no Brasil, algumas editoras aparentemente não diferenciam o uso das palavras "edição" e "reimpressão", o que por si só já é um entrave para o pesquisador. Às vezes, as "edições" trazem alguma diferença significativa (e.g. alteração no título), às vezes não.

Idealmente tentou-se eliminar reimpressões da contagem, mas no caso de se identificar alguma diferença qualquer (e.g. revisão da tradução), e na impossibilidade de se fazer uma crítica mais profunda por ora, considerou-se que se trata de edição diferente, dando a cada uma delas uma entrada individual na listagem final.

\section{Contribuições previstas}

Os dados obtidos pela pesquisa feita permitem uma vasta gama de comentários e análises. Além disso, pesquisa similar poderia, agora, ser feita com relação a obras de poesia, ensaios, biografias etc. - muitas das quais se excluiu com pesar do escopo.

Com pouquíssimas exceções, todas as traduções publicadas aqui datam de obras do princípio do século XX em diante, pertencendo, portanto, ao período pós-reabertura do Japão aos países ocidentais. Uma das exceções bastante significativas é a obra O livro do travesseiro (『枕草子』), escrita por uma dama da corte imperial japonesa, no século $X$, e publicada em português em 2013.

É também interessante notar que as publicações nacionais vêm tentando cobrir em boa medida tanto autores considerados clássicos do cânone moderno nipônico, como Natsume Soseki (夏目漱石) e Ryunosuke Akutagawa (芥川龍之介), quanto best-sellers contemporâneos, como, por exemplo, a autora de suspense Natsuo Kirino (桐野夏生) e a mestra do horror Kanae Minato (湊かなえ).

No entanto, é visível que a publicação dos autores japoneses no Brasil não está diretamente ligada ao mercado editorial japonês propriamente dito, e sim ao mercado editorial internacional. Pouquíssimos são os autores que são rapidamente publicados no Brasil: se olharmos a lista das nove obras que 
foram aqui publicadas nos dois anos subsequentes à sua publicação original, destacam-se os nomes de Shusaku Endo (遠藤周作) e Haruki Murakami (村 上春樹). Esse fato provavelmente se justifica pelo grande sucesso que esses dois autores fazem fora do Japão, especialmente nos EUA, animando assim editoras nacionais a tentarem investir nessa mesma corrente.

No caso de Haruki Murakami, essa tendência tem seguido bastante firme nas últimas duas décadas. Murakami é o autor japonês mais publicado no país ultimamente. Suas obras têm sido consistentemente editadas e reeditadas desde o início deste século. Hoje, elas já somam dezesseis títulos (alguns divididos em mais de um tomo) em apenas vinte anos.

Outros autores dignos de menção na lista dos favoritos das editoras brasileiras são o vencedor do Prêmio Nobel de 1968, Yasunari Kawabata (川 端康成), e os igualmente aclamados Yukio Mishima (三島由紀夫) e Jun'ichiro Tanizaki (谷崎潤一郎). Ultimamente, esses três autores canônicos na literatura japonesa do século $X X$ têm recebido apenas publicações esporádicas, mas já possuem cerca de dez títulos cada (com diversas reedições), disponíveis em português brasileiro.

Além disso, é notável também a situação do contista Akutagawa, provavelmente o único autor que sempre foi publicado aqui em traduções diretas do japonês. Há publicações de obras suas a partir dos anos de 1960, mas as traduções diretas do japonês no Brasil só se tornaram prática dominante a partir dos anos 1990 (CUNHA, 2015, p. 66).

Infelizmente, como dito anteriormente, muitas edições não indicam se a tradução apresentada foi direta ou indireta, de modo que o caso de Akutagawa, por exemplo, só fica claro por serem figuras conhecidas no meio dos Estudos Japoneses seus primeiros tradutores (José Yamashiro e Antônio Nojiri). Para outros casos, seria, portanto, importante haver mais pesquisa sobre os tradutores, mas vale notar aqui os trabalhos já realizados por Fabio Kato (2006), Andrei Cunha (2015) e Matheus Gonçalves (2017) a esse respeito. No quadro das obras, indicamos se a tradução era direta ou indireta apenas quando essa informação era óbvia (seja por indicação na obra ou por conhecermos seu tradutor). 


\section{Considerações finais}

Em conclusão, acredita-se que muitas outras pesquisas poderão ser feitas a partir dos dados obtidos - seja por correção ou complementação, ou ainda na análise de obras e edições identificadas. É importante notar que muitas das edições listadas, sendo antigas, encontram-se esgotadas, esquecidas pelo público e desconhecidas pelos pesquisadores da área dos Estudos Japoneses, de modo que recuperar a memória dessas publicações permitirá novas reflexões.

Possíveis desdobramentos dessa pesquisa que podem resultar em outros trabalhos interessantes a se mencionar são, por exemplo, pesquisas sobre a primeira obra japonesa a ser publicada no Brasil, A imagem de bronze, e sua tradutora, Zenaide Andréa, e também sobre o caso da obra Rua sem Sol, cuja tradução foi atribuída a Jorge Amado. É de se supor que essas duas, assim como a maioria das obras publicadas antes dos anos 1990, sejam de tradução indireta, porém essa informação não consta no livro impresso, de modo que também é algo a ser investigado.

Um outro ponto que talvez valesse mais atenção dos pesquisadores é prática do mercado editorial brasileiro sobre o uso da palavra "edição", sem diferenciá-la, por vezes, de "reimpressão". Esse fato, juntamente com falta de clareza sobre a tradução ser direta ou indireta, e ainda uma outra prática do passado (hoje superada) de não indicar o ano de publicação, é um grande entrave a pesquisas como esta, de modo que mereceria ser objeto de estudo próprio.

Sobre a apresentação dos dados, deve-se notar que estão divididos em dois quadros diferentes para facilitar a visualização do leitor. O primeiro quadro contém livros de autoria única e o segundo, coletâneas mistas. Breves comentários figuram em notas de fim, assim como os nomes dos tradutores quando eram mais de três para um único título. Ao lado do nome do(s) tradutor(es) consta, quando possível, a informação de se a tradução foi feita diretamente do japonês ou não. A transliteração da língua japonesa para nosso alfabeto segue a da publicação, a menos que indicado em contrário. 


\section{Referências}

A SCENA MUDA. Rio de Janeiro, ano 20, n. 1043, p. 27, 18 mar. 1941. Disponível em: http://memoria.bn.br/DocReader/084859/37039. Acesso em 11 abril 2019.

CUNHA, Andrei dos Santos. O Japão em tradução: textos brasileiros. Tradução em Revista, Rio de Janeiro, n. 18, 2015. Disponível em: https://www.maxwell.vrac.puc-rio.br/24853/24853.PDFXXvmi=. Acesso em 16 mar. 2021.

GONÇALVES, Matheus. 'Joseizou no senmonka': quando Paulo Hecker Filho traduziu Yasunari Kawabata. Hon no mushi: estudos multidisciplinares japoneses, Manaus, v. 2, n. 3, 2017. Disponível em: https://periodicos.ufam.edu.br/HonNoMushi/article/view/4080. Acesso m 16 mar. 2021.

KATO, Fabio Yoshiaki. Edições brasileiras de ficção japonesa. 2006. 195 f. Trabalho de conclusão de curso (Graduação em Comunicação Social, com habilitação em Editoração) - Universidade de São Paulo, São Paulo, 2006.

\section{Resumo}

Este texto serve de introdução aos dados resultantes de pesquisa exaustiva que procura identificar todas as diferentes obras de ficção japonesa em prosa publicadas no Brasil, em suas diversas edições, excetuando-se reimpressões, até 2020. Expõe-se a proposta da pesquisa, motivação, público-alvo, metodologia e contribuição esperada. A parte dos dados apresenta, em dois quadros, as 171 edições encontradas, com comentários em notas de fim. A divisão em dois quadros separou obras de autoria única das coletâneas mistas, possibilitando exposição de todos os autores e tradutores. Quando possível, indica-se se a tradução foi feita diretamente do japonês ou não.

Palavras-chave: Literatura japonesa; Ficção japonesa; Prosa japonesa; Tradução japonês-português

\section{Abstract}

This text is an introduction to data resulting from an exhaustive research that seeks to identify all the different works of Japanese fiction in prose published 
in Brazil, in their various editions, except for reprinting, up to 2020. It presents research proposal, motivation, target audience, methodology, and expected contribution. The data part presents, in two tables, the 171 editions found, with comments in endnotes. The two tables separated works of single authorship from mixed collections, allowing to clarify all authors and translators. When it is possible, it is indicated if the translation was made directly from Japanese language or not.

Keywords: Japanese literature; Japanese fiction; Japanese prose; JapanesePortuguese translation 


\section{Ficção Japonesa em Prosa Publicada no Brasil}

Quadro 1: Obras de ficção em prosa da literatura japonesa publicadas no Brasil ordenadas por sobrenome/prenome do autor e, em seguida, pelo ano de publicação no Brasil ("Ano BR", sendo "Ano JP" o ano de publicação original no Japão). O “d" e o "i" sobrescritos ao lado do nome do(s) tradutor(es) indicam se a tradução foi direta ou indireta, nos casos em que essa informação é sabida.

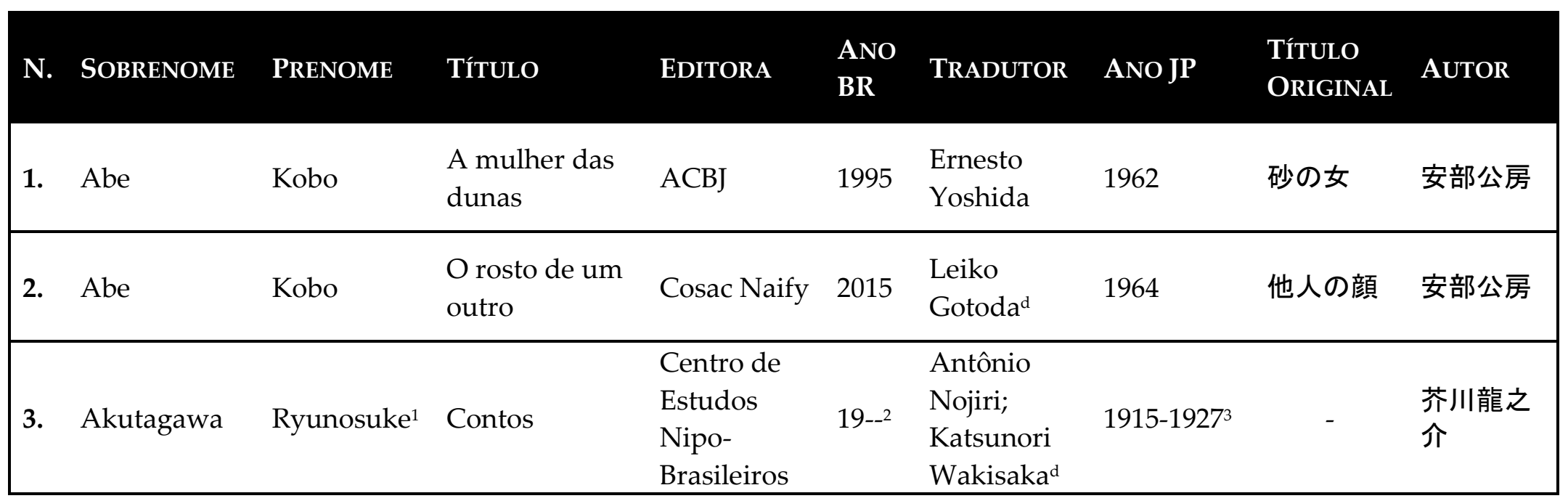




\begin{tabular}{|c|c|c|c|c|c|c|c|c|c|}
\hline 4. & Akutagawa & Ryunosuke & $\begin{array}{l}\text { Rashomon e } \\
\text { outros contos }\end{array}$ & $\begin{array}{l}\text { Massao } \\
\text { Ohno }\end{array}$ & 1961 & $\begin{array}{l}\text { Antônio } \\
\text { Nojirid }^{\mathrm{d}}\end{array}$ & $1915-1927$ & - & $\begin{array}{l}\text { 芥川龍之 } \\
\text { 介 }\end{array}$ \\
\hline 5. & Akutagawa & Ryunosuke & $\begin{array}{l}\text { Rashomon e } \\
\text { outros contos: } \\
\text { tema do filme } \\
\text { de Akira } \\
\text { Kurosawa }\end{array}$ & $\begin{array}{l}\text { Civilização } \\
\text { Brasileira; } \\
\text { Massao } \\
\text { Ohno }\end{array}$ & 1981 & $\begin{array}{l}\text { Antônio } \\
\text { Nojiri; } \\
\text { Katsunori } \\
\text { Wakisaka }^{\mathrm{d}}\end{array}$ & $1915-1927$ & - & $\begin{array}{l}\text { 芥川龍之 } \\
\text { 介 }\end{array}$ \\
\hline 6. & Akutagawa & Ryunosuke & $\begin{array}{l}\text { Rashomon e } \\
\text { outras } \\
\text { histórias }\end{array}$ & Paulicéia & 1992 & $\begin{array}{l}\text { Madalena } \\
\text { Hashimoto } \\
\text { Cordaro; } \\
\text { Junko Ota }^{\mathrm{d}} \\
\end{array}$ & $1915-1927$ & - & $\begin{array}{l}\text { 芥川龍之 } \\
\text { 介 }\end{array}$ \\
\hline 7. & Akutagawa & Ryunosuke & $\begin{array}{l}\text { Contos } \\
\text { fantásticos }\end{array}$ & $\mathrm{Z}$ & 2003 & $\begin{array}{l}\text { Diogo } \\
\text { Kaupatez }^{\mathrm{d}}\end{array}$ & 1915-1927 & - & $\begin{array}{l}\text { 芥川龍之 } \\
\text { 介 }\end{array}$ \\
\hline 8. & Akutagawa & Ryunosuke & $\begin{array}{l}\text { O fio da } \\
\text { aranha }^{5}\end{array}$ & Shinseken & 2003 & $\begin{array}{l}\text { Maurício } \\
\text { Crespo }^{\mathrm{d}}\end{array}$ & 1918 & 蜘蛛の糸 & $\begin{array}{l}\text { 芥川龍之 } \\
\text { 介 }\end{array}$ \\
\hline 9. & Akutagawa & Ryunosuke & $\begin{array}{l}\text { Toshishun: o } \\
\text { conto chinês } \\
\text { do jovem } \\
\text { pródigo e o } \\
\text { ermitão }^{5}\end{array}$ & Shinseken & 2004 & $\begin{array}{l}\text { Maurício } \\
\text { Crespo }^{\mathrm{d}}\end{array}$ & 1920 & 杜子春 & $\begin{array}{l}\text { 芥川龍之 } \\
\text { 介 }\end{array}$ \\
\hline
\end{tabular}




\begin{tabular}{|c|c|c|c|c|c|c|c|c|}
\hline 10. Akutagawa & Ryunosuke & $\begin{array}{l}\text { Rashomon e } \\
\text { outros contos }\end{array}$ & Hedra & 2008 & $\begin{array}{l}\text { Madalena } \\
\text { Hashimoto } \\
\text { Cordaro; } \\
\text { Junko Otad }\end{array}$ & $1915-1927$ & - & $\begin{array}{l}\text { 芥川龍之 } \\
\text { 介 }\end{array}$ \\
\hline 11. Akutagawa & Ryunosuke & $\begin{array}{l}\text { Kappa e o } \\
\text { levante } \\
\text { imaginário }\end{array}$ & $\begin{array}{l}\text { Estação } \\
\text { Liberdade }\end{array}$ & 2010 & $\begin{array}{l}\text { Shintaro } \\
\text { Hayashi }^{\mathrm{d}}\end{array}$ & $1915-1927$ & - & $\begin{array}{l}\text { 芥川龍之 } \\
\text { 介 }\end{array}$ \\
\hline 12. Arikawa & Hiro & $\begin{array}{l}\text { Relatos de um } \\
\text { gato viajante }\end{array}$ & Alfaguara & 2017 & Rita Kohld & 2012 & $\begin{array}{l}\text { 旅猫リポ } \\
\text { ート }\end{array}$ & 有川浩 \\
\hline 13. Dazai & Osamu & Pôr do sol & $\begin{array}{l}\text { Centro de } \\
\text { Estudos } \\
\text { Nipo- } \\
\text { Brasileiros }\end{array}$ & 19--7 & $\begin{array}{l}\text { Antônio } \\
\text { Nojiri }^{\mathrm{d}}\end{array}$ & 1947 & 斜陽 & 太宰治 \\
\hline 14. Dazai & Osamu & Pôr do sol & $\begin{array}{l}\text { Civilização } \\
\text { Brasileira; } \\
\text { Massao } \\
\text { Ohno }\end{array}$ & 1981 & $\begin{array}{l}\text { Antônio } \\
\text { Nojiri }^{\mathrm{d}}\end{array}$ & 1947 & 斜陽 & 太宰治 \\
\hline 15. Dazai & Osamu & $\begin{array}{l}\text { Declínio de } \\
\text { um homem }\end{array}$ & $\begin{array}{l}\text { Estação } \\
\text { Liberdade }\end{array}$ & 2015 & $\begin{array}{l}\text { Ricardo } \\
\text { Machado }^{d}\end{array}$ & 1948 & 人間失格 & 太宰治 \\
\hline 16. Endo & Shusaku & $\begin{array}{l}\text { Admirável } \\
\text { idiota }\end{array}$ & $\begin{array}{l}\text { Civilização } \\
\text { Brasileira }\end{array}$ & 1979 & $\begin{array}{l}\text { Roberto } \\
\text { Raposo }\end{array}$ & 1959 & $\begin{array}{l}\text { おバカさ } \\
\text { ん }\end{array}$ & 遠藤周作 \\
\hline
\end{tabular}




\begin{tabular}{|c|c|c|c|c|c|c|c|c|}
\hline 17. Endo & Shusaku & Mar e veneno & $\begin{array}{l}\text { Civilização } \\
\text { Brasileira }\end{array}$ & 1979 & $\begin{array}{l}\text { Roberto } \\
\text { Raposo }^{\mathrm{i}}\end{array}$ & 1958 & 海と毒薬 & 遠藤周作 \\
\hline 18. Endo & Shusaku & O silêncio & $\begin{array}{l}\text { Civilização } \\
\text { Brasileira }\end{array}$ & 1979 & $\begin{array}{l}\text { Edyla } \\
\text { Mangabeira } \\
\text { Unger }^{\mathrm{i}}\end{array}$ & 1966 & 沈默 & 遠藤周作 \\
\hline 19. Endo & Shusaku & O silêncio & $\begin{array}{l}\text { Círculo do } \\
\text { Livro }\end{array}$ & 1982 & $\begin{array}{l}\text { Edyla } \\
\text { Mangabeira } \\
\text { Unger }^{i}\end{array}$ & 1966 & 沈黙 & 遠藤周作 \\
\hline 20. Endo & Shusaku & O samurai & Nórdica & 1985 & $\begin{array}{l}\text { Luís } \\
\text { Horácio da } \\
\text { Mattai }^{\text {i }}\end{array}$ & 1980 & 侍 & 遠藤周作 \\
\hline 21. Endo & Shusaku & O samurai & $\begin{array}{l}\text { Círculo do } \\
\text { Livro }\end{array}$ & 1985 & $\begin{array}{l}\text { Luís } \\
\text { Horácio da } \\
\text { Matta }^{\mathrm{i}}\end{array}$ & 1980 & 侍 & 遠藤周作 \\
\hline 22. Endo & Shusaku & Escândalo & Rocco & 1988 & $\begin{array}{l}\text { Maria } \\
\text { Helena } \\
\text { Torres }^{i}\end{array}$ & 1986 & $\begin{array}{l}\text { スキャン } \\
\text { ダル }\end{array}$ & 遠藤周作 \\
\hline 23. Endo & Shusaku & $\begin{array}{l}\text { Rio Profundo } \\
\text { Ganges }\end{array}$ & Mercuryo & 1995 & $\begin{array}{l}\text { Ricardo } \\
\text { Gouveia }^{\mathrm{i}}\end{array}$ & 1993 & 深い河 & 遠藤周作 \\
\hline 24. Endo & Shusaku & Silêncio & $\begin{array}{l}\text { Planeta de } \\
\text { Livros; } \\
\text { Tusquets }\end{array}$ & 2011 & $\begin{array}{l}\text { Mário } \\
\text { Vilela }^{i}\end{array}$ & 1966 & 沈黙 & 遠藤周作 \\
\hline
\end{tabular}




\begin{tabular}{|c|c|c|c|c|c|c|c|c|c|}
\hline 25. & Endo & Shusaku & Silêncio & $\begin{array}{l}\text { Planeta de } \\
\text { Livros; } \\
\text { Tusquets }^{8}\end{array}$ & 2016 & $\begin{array}{l}\text { Mário } \\
\text { Vilela }^{\mathrm{i}}\end{array}$ & 1966 & 沈黙 & 遠藤周作 \\
\hline 26. & Endo & Shusaku & Samurai & $\begin{array}{l}\text { Planeta de } \\
\text { Livros; } \\
\text { Tusquets }\end{array}$ & 2017 & $\begin{array}{l}\text { Mário } \\
\text { Vilela }^{i}\end{array}$ & 1980 & 侍 & 遠藤周作 \\
\hline 27. & Endo & Shusaku & Escândalo & $\begin{array}{l}\text { Planeta de } \\
\text { Livros; } \\
\text { Tusquets }\end{array}$ & 2019 & $\begin{array}{l}\text { Mário } \\
\text { Vilela; } \\
\text { Aline } \\
\text { Storto } \\
\text { Pereira } \\
\end{array}$ & 1986 & $\begin{array}{l}\text { スキャン } \\
\text { ダル }\end{array}$ & 遠藤周作 \\
\hline 28. & Go & Shizuko & Réquiem & Record & 1994 & $\begin{array}{l}\text { Sonia } \\
\text { Moreira }^{9}\end{array}$ & 1973 & $\begin{array}{l}\text { れくいえ } \\
\text { む }\end{array}$ & 郷静子 \\
\hline & Hashida & Sugako & $\begin{array}{l}\text { Haru e Natsu: } \\
\text { as cartas que } \\
\text { não chegaram }\end{array}$ & $\begin{array}{l}\text { Kaleidos } \\
\text { Primus }\end{array}$ & 2005 & $\begin{array}{l}\text { Masato } \\
\text { Ninomiya; } \\
\text { Sonia R. } \\
\text { Longhi } \\
\text { Ninomiyad }^{d}\end{array}$ & 2005 & $\begin{array}{l}\text { ハルとナ } \\
\text { ツ一届か } \\
\text { なかった } \\
\text { 手紙 }\end{array}$ & $\begin{array}{l}\text { 橋田壽賀 } \\
\text { 子 }\end{array}$ \\
\hline & Hayashi & Fumiko & $\begin{array}{l}\text { Memórias de } \\
\text { uma errante }\end{array}$ & $\begin{array}{l}\text { Movimento; } \\
\text { Fundação } \\
\text { Japão }\end{array}$ & 1996 & $\begin{array}{l}\text { Meiko } \\
\text { Shimon }^{\mathrm{d}}\end{array}$ & 1930 & 放浪記 & 林芙美子 \\
\hline
\end{tabular}




\begin{tabular}{|c|c|c|c|c|c|c|c|c|}
\hline 31. Ibuse & Masuji & Chuva negra & Marco Zero & 1988 & $\begin{array}{l}\text { Reinaldo } \\
\text { Guarany }\end{array}$ & 1966 & 黒い雨 & 井伏鱒二 \\
\hline 32. Ibuse & Masuji & Chuva negra & $\begin{array}{l}\text { Estação } \\
\text { Liberdade }\end{array}$ & 2011 & $\begin{array}{l}\text { Jefferson } \\
\text { José } \\
\text { Teixeirad }^{\mathrm{d}}\end{array}$ & 1966 & 黒い雨 & 井伏鱒二 \\
\hline 33. Inoue & Yasushi & $\begin{array}{l}\text { A espingarda } \\
\text { de caça }\end{array}$ & Brasiliense & 1988 & $\begin{array}{l}\text { Yolanda } \\
\text { Steidel de } \\
\text { Toledo }\end{array}$ & 1949 & 猟銃 & 井上靖 \\
\hline 34. Inoue & Yasushi & O fuzil de caça & $\begin{array}{l}\text { Estação } \\
\text { Liberdade }\end{array}$ & 2010 & $\begin{array}{l}\text { Jefferson } \\
\text { José } \\
\text { Teixeirad }^{\mathrm{d}}\end{array}$ & 1949 & 猟銃 & 井上靖 \\
\hline 35. Inoue & Yasushi & $\begin{array}{l}\text { O Castelo de } \\
\text { Yodo }\end{array}$ & $\begin{array}{l}\text { Estação } \\
\text { Liberdade }\end{array}$ & 2013 & $\begin{array}{l}\text { Andrei } \\
\text { Cunha }^{\mathrm{d}}\end{array}$ & 1955 & $\begin{array}{l}\text { 淀どの日 } \\
\text { 記 }\end{array}$ & 井上靖 \\
\hline 36. Ishikawa & Tatsuzô & $\begin{array}{l}\text { Sôbô: uma } \\
\text { saga da } \\
\text { imigração } \\
\text { japonesa }\end{array}$ & Ateliê & 2008 & $* 10$ & 1935 & 蒼讯 & 石川達三 \\
\hline 37. Kaga & Otohiko & O vento leste & $\begin{array}{l}\text { Estação } \\
\text { Liberdade }\end{array}$ & 2014 & $\begin{array}{l}\text { Pedro } \\
\text { Barros }^{\mathrm{i}}\end{array}$ & 1982 & $\begin{array}{l}\text { 錨のない } \\
\text { 船 }\end{array}$ & 加賀乙彦 \\
\hline
\end{tabular}




\begin{tabular}{|c|c|c|c|c|c|c|c|c|}
\hline 38. Kanehara & Hitomi & $\begin{array}{l}\text { Cobras e } \\
\text { piercings }\end{array}$ & $\begin{array}{l}\text { Ediouro; } \\
\text { Geração } \\
\text { Editorial }\end{array}$ & 2007 & $\begin{array}{l}\text { Jefferson } \\
\text { José } \\
\text { Teixeira }^{\mathrm{d}} \\
\end{array}$ & 2003 & $\begin{array}{l}\text { 蛇にピア } \\
\text { ス }\end{array}$ & $\begin{array}{l}\text { 金原ひと } \\
\text { み }\end{array}$ \\
\hline 39. Katayama & Kyoichi & $\begin{array}{l}\text { Um grito de } \\
\text { amor do } \\
\text { centro do } \\
\text { mundo }\end{array}$ & Alfaguara & 2010 & $\begin{array}{l}\text { Lica } \\
\text { Hashimoto }^{\mathrm{d}}\end{array}$ & 2001 & $\begin{array}{l}\text { 世界の中 } \\
\text { 心で、愛 } \\
\text { をさけぶ }\end{array}$ & 片山恭一 \\
\hline 40. Kawabata & Yasunari & $\begin{array}{l}\text { Nuvens de } \\
\text { pássaros } \\
\text { brancos }\end{array}$ & $\begin{array}{l}\text { Nova } \\
\text { Fronteira }\end{array}$ & 1969 & $\begin{array}{l}\text { Paulo } \\
\text { Hecker } \\
\text { Filho }^{\mathrm{i}} \\
\end{array}$ & 1949-1952 & 千羽鶴 & 川端康成 \\
\hline 41. Kawabata & Yasunari & País das neves & $\begin{array}{l}\text { Nova } \\
\text { Fronteira }\end{array}$ & 1969 & $\begin{array}{l}\text { Marina } \\
\text { Colasanti }\end{array}$ & 1935-1948 & 雪国 & 川端康成 \\
\hline 42. Kawabata & Yasunari & $\begin{array}{l}\text { Nuvem de } \\
\text { pássaros } \\
\text { brancos } \\
\end{array}$ & $\begin{array}{l}\text { Opera } \\
\text { Mundi }\end{array}$ & 1973 & $\begin{array}{l}\text { Paulo } \\
\text { Hecker } \\
\text { Filho }^{\mathrm{i}} \\
\end{array}$ & 1949-1952 & 千羽鶴 & 川端康成 \\
\hline 43. Kawabata & Yasunari & País das neves & $\begin{array}{l}\text { Círculo do } \\
\text { Livro }\end{array}$ & 1974 & $\begin{array}{l}\text { Marina } \\
\text { Colasanti }\end{array}$ & 1935-1948 & 雪国 & 川端康成 \\
\hline 44. Kawabata & Yasunari & Kyoto & $\begin{array}{l}\text { Abril } \\
\text { Cultural }\end{array}$ & 1985 & $\begin{array}{l}\text { Virgílio } \\
\text { Martinho }^{11}\end{array}$ & 1962 & 古都 & 川端康成 \\
\hline
\end{tabular}




\begin{tabular}{|c|c|c|c|c|c|c|c|c|}
\hline 45. Kawabata & Yasunari & $\begin{array}{l}\text { Beleza e } \\
\text { tristeza }\end{array}$ & Globo & 1988 & $\begin{array}{l}\text { Alberto } \\
\text { Alexandre } \\
\text { Martins }^{i} \\
\end{array}$ & 1964 & $\begin{array}{l}\text { 美しさと } \\
\text { 哀しみと }\end{array}$ & 川端康成 \\
\hline 46. Kawabata & Yasunari & $\begin{array}{l}\text { A casa das } \\
\text { belas } \\
\text { adormecidas }\end{array}$ & $\begin{array}{l}\text { Estação } \\
\text { Liberdade }\end{array}$ & 2004 & $\begin{array}{l}\text { Meiko } \\
\text { Shimon }^{\mathrm{d}}\end{array}$ & 1961 & $\begin{array}{l}\text { 眠れる美 } \\
\text { 女 }\end{array}$ & 川端康成 \\
\hline 47. Kawabata & Yasunari & $\begin{array}{l}\text { Beleza e } \\
\text { tristeza }\end{array}$ & Globo $^{12}$ & 2004 & $\begin{array}{l}\text { Alberto } \\
\text { Alexandre } \\
\text { Martins }^{i} \\
\end{array}$ & 1964 & $\begin{array}{l}\text { 美しさと } \\
\text { 哀しみと }\end{array}$ & 川端康成 \\
\hline 48. Kawabata & Yasunari & $\begin{array}{l}\text { O país das } \\
\text { neves }\end{array}$ & $\begin{array}{l}\text { Estação } \\
\text { Liberdade }\end{array}$ & 2004 & $\begin{array}{l}\text { Neide } \\
\text { Nagae }^{\mathrm{d}}\end{array}$ & $1935-1948$ & 雪国 & 川端康成 \\
\hline 49. Kawabata & Yasunari & Kyoto & $\begin{array}{l}\text { Estação } \\
\text { Liberdade }\end{array}$ & 2006 & $\begin{array}{l}\text { Meiko } \\
\text { Shimon }^{\mathrm{d}}\end{array}$ & 1962 & 古都 & 川端康成 \\
\hline 50. Kawabata & Yasunari & Mil Tsurus & $\begin{array}{l}\text { Estação } \\
\text { Liberdade }\end{array}$ & 2006 & Drik Sada $^{d}$ & 1949-1952 & 千羽鶴 & 川端康成 \\
\hline 51. Kawabata & Yasunari & $\begin{array}{l}\text { A dançarina } \\
\text { de Izu }\end{array}$ & $\begin{array}{l}\text { Estação } \\
\text { Liberdade }\end{array}$ & 2008 & $\begin{array}{l}\text { Carlos } \\
\text { Hiroshi } \\
\text { Usirono }^{\mathrm{d}} \\
\end{array}$ & 1926 & $\begin{array}{l}\text { 伊豆の踊 } \\
\text { 子 }\end{array}$ & 川端康成 \\
\hline 52. Kawabata & Yasunari & $\begin{array}{l}\text { Beleza e } \\
\text { tristeza }\end{array}$ & Globo $^{13}$ & 2008 & $\begin{array}{l}\text { Alberto } \\
\text { Alexandre } \\
\text { Martins }^{i}\end{array}$ & 1964 & $\begin{array}{l}\text { 美しさと } \\
\text { 哀しみと }\end{array}$ & 川端康成 \\
\hline
\end{tabular}




\begin{tabular}{|c|c|c|c|c|c|c|c|c|}
\hline 53. Kawabata & Yasunari & $\begin{array}{l}\text { Contos da } \\
\text { palma da mão }\end{array}$ & $\begin{array}{l}\text { Estação } \\
\text { Liberdade }\end{array}$ & 2008 & $\begin{array}{l}\text { Meiko } \\
\text { Shimon }^{\mathrm{d}}\end{array}$ & 1971 & 掌の小説 & 川端康成 \\
\hline 54. Kawabata & Yasunari & $\begin{array}{l}\text { O som da } \\
\text { montanha }\end{array}$ & $\begin{array}{l}\text { Estação } \\
\text { Liberdade }\end{array}$ & 2009 & $\begin{array}{l}\text { Meiko } \\
\text { Shimon }^{\mathrm{d}}\end{array}$ & 1949-1954 & 山の音 & 川端康成 \\
\hline 55. Kawabata & Yasunari & O lago & $\begin{array}{l}\text { Estação } \\
\text { Liberdade }\end{array}$ & 2010 & $\begin{array}{l}\text { Meiko } \\
\text { Shimon }\end{array}$ & 1954 & $\begin{array}{l}\text { みづうみ } \\
(\text { みずう } \\
\text { み })^{14} \\
\end{array}$ & 川端康成 \\
\hline 56. Kawabata & Yasunari & $\begin{array}{l}\text { O mestre de } \\
\text { go }\end{array}$ & $\begin{array}{l}\text { Estação } \\
\text { Liberdade }\end{array}$ & 2011 & $\begin{array}{l}\text { Meiko } \\
\text { Shimon }^{\mathrm{d}}\end{array}$ & 1951-1954 & 名人 & 川端康成 \\
\hline 57. Kawabata & Yasunari & $\begin{array}{l}\text { A gangue } \\
\text { escarlate de } \\
\text { Asakusa }\end{array}$ & $\begin{array}{l}\text { Estação } \\
\text { Liberdade }\end{array}$ & 2013 & $\begin{array}{l}\text { Meiko } \\
\text { Shimon }^{\mathrm{d}}\end{array}$ & 1930 & 浅草紅團 & 川端康成 \\
\hline 58. Kawakami & Hiromi & $\begin{array}{l}\text { Quinquilharias } \\
\text { Nakano }\end{array}$ & $\begin{array}{l}\text { Estação } \\
\text { Liberdade }\end{array}$ & 2010 & $\begin{array}{l}\text { Jefferson } \\
\text { José } \\
\text { Teixeira }^{d}\end{array}$ & 2005 & $\begin{array}{l}\text { 古道具中 } \\
\text { 野商店 }\end{array}$ & 川上弘美 \\
\hline 59. Kawakami & Hiromi & $\begin{array}{l}\text { A valise do } \\
\text { professor }\end{array}$ & $\begin{array}{l}\text { Estação } \\
\text { Liberdade }\end{array}$ & 2012 & $\begin{array}{l}\text { Jefferson } \\
\text { José } \\
\text { Teixeira }^{d}\end{array}$ & 2001 & $\begin{array}{l}\text { センセイ } \\
\text { の鞄 }\end{array}$ & 川上弘美 \\
\hline 60. Kirino & Natsuo & Do outro lado & Rocco & 2009 & $\begin{array}{l}\text { Roberto } \\
\text { Wander } \\
\text { Nóbrega }^{\mathrm{i}}\end{array}$ & 1997 & $\begin{array}{l}\mathrm{OUT} \text { (ア } \\
\text { ウト) }\end{array}$ & 桐野夏生 \\
\hline
\end{tabular}




\begin{tabular}{|c|c|c|c|c|c|c|c|c|}
\hline 61. Kirino & Natsuo & Grotescas & Rocco & 2011 & $\begin{array}{l}\text { Alexandre } \\
\text { D'Elia }^{\prime}\end{array}$ & 2003 & $\begin{array}{l}\text { グロテス } \\
\text { ク }\end{array}$ & 桐野夏生 \\
\hline 62. Kirino & Natsuo & $\begin{array}{l}\text { O conto da } \\
\text { Deusa }\end{array}$ & Rocco & 2014 & $\begin{array}{l}\text { Alexandre } \\
\text { D'Elia }^{\mathrm{i}}\end{array}$ & 2009 & 女神記 & 桐野夏生 \\
\hline 63. Kita & Morio & $\begin{array}{l}\text { Um hospício } \\
\text { no Japão ( } 2 \\
\text { tomos) }\end{array}$ & Marco Zero & $\begin{array}{l}1990- \\
1993\end{array}$ & $* 15$ & 1964 & $\begin{array}{l}\text { 榆家の人 } \\
\text { びと }\end{array}$ & 北杜夫 \\
\hline 64. Kohara & Kazuno & $\begin{array}{l}\text { A casa } \\
\text { assombrada }\end{array}$ & Cosac Naify & 2010 & $\begin{array}{l}\text { Heloísa } \\
\text { Prieto }\end{array}$ & $\begin{array}{l}2008 \\
(2009)\end{array}$ & $\begin{array}{l}\text { The } \\
\text { Haunted } \\
\text { House (お } \\
\text { ばけやし } \\
\text { きにおひ } \\
\text { っこし) }{ }^{16}\end{array}$ & 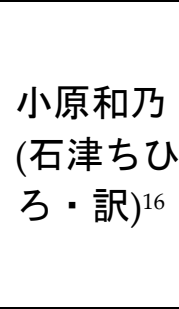 \\
\hline 65. $\begin{array}{l}\text { Matsumoto } \\
\text { (Matumoto) }^{17}\end{array}$ & $\begin{array}{l}\text { Seicho } \\
\text { (Seityo) }\end{array}$ & $\begin{array}{l}\text { Dois pontos e } \\
\text { uma reta }\end{array}$ & $\begin{array}{l}\text { Clube do } \\
\text { Livro }\end{array}$ & 1970 & $\begin{array}{l}\text { Shinobu } \\
\text { Saiki }^{\mathrm{d}}\end{array}$ & 1958 & 点と線 & 松本清張 \\
\hline 66. $\begin{array}{l}\text { Matsumoto } \\
{\text { (Matumoto })^{17}}^{\text {Matula }}\end{array}$ & $\begin{array}{l}\text { Seicho } \\
\text { (Seityo) }\end{array}$ & $\begin{array}{l}\text { Foco de } \\
\text { convergências }\end{array}$ & $\begin{array}{l}\text { Clube do } \\
\text { Livro }\end{array}$ & 1976 & $\begin{array}{l}\text { Shinobu } \\
\text { Saiki }^{18}\end{array}$ & 1959 & $\begin{array}{l}\text { ゼロの焦 } \\
\text { 点 }\end{array}$ & 松本清張 \\
\hline 67. Minato & Kanae & Confissões & Vestígio & 2017 & $\begin{array}{l}\text { Rogério } \\
\text { Bettoni }\end{array}$ & 2008 & 告白 & 湊かなえ \\
\hline
\end{tabular}




\begin{tabular}{|c|c|c|c|c|c|c|c|c|}
\hline 68. Minato & Kanae & Confissões & Gutenberg & 2019 & $\begin{array}{l}\text { Rogério } \\
\text { Bettoni }\end{array}$ & 2008 & 告白 & 湊かなえ \\
\hline 69. Minato & Kanae & Penitência & Gutenberg & 2019 & $\begin{array}{l}\text { Elisa } \\
\text { Nazarian }\end{array}$ & 2009 & 贖罪 & 湊かなえ \\
\hline 70. Mishima & Yukio & $\begin{array}{l}\text { Depois do } \\
\text { banquete }\end{array}$ & Edinova & 1968 & $\begin{array}{l}\text { Vera } \\
\text { Pedrosa }\end{array}$ & 1960 & 宴のあと & $\begin{array}{l}\text { 三島由紀 } \\
\text { 夫 }\end{array}$ \\
\hline 71. Mishima & Yukio & $\begin{array}{l}\text { Confissões de } \\
\text { uma máscara }\end{array}$ & Vertente & 1976 & $\begin{array}{l}\text { Manoel } \\
\text { Paulo } \\
\text { Ferreira }\end{array}$ & 1949 & $\begin{array}{l}\text { 假面の告 } \\
\text { 白 } \\
\text { (仮面の } \\
\text { 告白) }\end{array}$ & $\begin{array}{l}\text { 三島由紀 } \\
\text { 夫 }\end{array}$ \\
\hline 72. Mishima & Yukio & $\begin{array}{l}\text { Confissões de } \\
\text { uma máscara }\end{array}$ & $\begin{array}{l}\text { Círculo do } \\
\text { Livro }\end{array}$ & $\begin{array}{l}1977- \\
86^{19}\end{array}$ & $\begin{array}{l}\text { Manoel } \\
\text { Paulo } \\
\text { Ferreira }\end{array}$ & 1949 & $\begin{array}{l}\text { 假面の告 } \\
\text { 白 } \\
\text { (仮面の } \\
\text { 告白) }\end{array}$ & $\begin{array}{l}\text { 三島由紀 } \\
\text { 夫 }\end{array}$ \\
\hline 73. Mishima & Yukio & $\begin{array}{l}\text { O marinheiro } \\
\text { que perdeu as } \\
\text { graças do mar }\end{array}$ & Rocco & 1985 & $\begin{array}{l}\text { Waltensir } \\
\text { Dutra }\end{array}$ & 1963 & $\begin{array}{l}\text { 午後の电 } \\
\text { 航 }\end{array}$ & $\begin{array}{l}\text { 三島由紀 } \\
\text { 夫 }\end{array}$ \\
\hline 74. Mishima & Yukio & $\begin{array}{l}\text { Morte em } \\
\text { pleno verão }\end{array}$ & Rocco & 1986 & $\begin{array}{l}\text { Aulyde } \\
\text { Soares } \\
\text { Rodrigues } \\
\end{array}$ & 1953 & 真夏の死 & $\begin{array}{l}\text { 三島由紀 } \\
\text { 夫 }\end{array}$ \\
\hline
\end{tabular}




\begin{tabular}{|c|c|c|c|c|c|c|c|c|}
\hline 75. Mishima & Yukio & $\begin{array}{l}\text { Mar da } \\
\text { Fertilidade }-1 \\
\text { Neve da } \\
\text { primavera }\end{array}$ & Brasiliense & 1986 & $\begin{array}{l}\text { Newton } \\
\text { Goldman }\end{array}$ & 1969 & $\begin{array}{l}\text { 豐饒の海 } \\
\text { (豊饒の } \\
\text { 海) } \\
\text { I. 春の雪 } \\
\end{array}$ & $\begin{array}{l}\text { 三島由紀 } \\
\text { 夫 }\end{array}$ \\
\hline 76. Mishima & Yukio & $\begin{array}{l}\text { Mar da } \\
\text { Fertilidade }-2 \\
\text { Cavalo } \\
\text { selvagem }\end{array}$ & Brasiliense & 1987 & $\begin{array}{l}\text { Isa Mara } \\
\text { Lando }\end{array}$ & 1969 & $\begin{array}{l}\text { 豐饒の海 } \\
\text { (豊饒の } \\
\text { 海) } \\
\text { II. 奔馬 }\end{array}$ & $\begin{array}{l}\text { 三島由紀 } \\
\text { 夫 }\end{array}$ \\
\hline 77. Mishima & Yukio & $\begin{array}{l}\text { Mar da } \\
\text { Fertilidade }-3 \\
\text { O templo da } \\
\text { aurora }\end{array}$ & Brasiliense & 1988 & $\begin{array}{l}\text { Isa Mara } \\
\text { Lando }\end{array}$ & 1970 & $\begin{array}{l}\text { 豐饒の海 } \\
\text { (豊饒の } \\
\text { 海) } \\
\text { III. 曉の寺 }\end{array}$ & $\begin{array}{l}\text { 三島由紀 } \\
\text { 夫 }\end{array}$ \\
\hline 78. Mishima & Yukio & $\begin{array}{l}\text { Mar da } \\
\text { Fertilidade }-4 \text {. } \\
\text { A queda do } \\
\text { anjo }\end{array}$ & Brasiliense & 1988 & $\begin{array}{l}\text { Isa Mara } \\
\text { Lando }\end{array}$ & 1971 & $\begin{array}{l}\text { 豐饒の海 } \\
\text { （豊饒の } \\
\text { 海） } \\
\text { IV. 天人 } \\
\text { 五衰 }\end{array}$ & $\begin{array}{l}\text { 三島由紀 } \\
\text { 夫 }\end{array}$ \\
\hline 79. Mishima & Yukio & $\begin{array}{l}\text { O templo do } \\
\text { pavilhão } \\
\text { dourado }\end{array}$ & Rocco & 1988 & $\begin{array}{l}\text { Eliana } \\
\text { Sabino }\end{array}$ & 1956 & 金閣寺 & $\begin{array}{l}\text { 三島由紀 } \\
\text { 夫 }\end{array}$ \\
\hline 80. Mishima & Yukio & $\begin{array}{l}\text { Cores } \\
\text { proibidas }\end{array}$ & $\begin{array}{l}\text { Cia. das } \\
\text { Letras }\end{array}$ & 2002 & $\begin{array}{l}\text { Jefferson } \\
\text { José } \\
\text { Teixeirad }^{\text {Teix }}\end{array}$ & 1953 & 禁色 & $\begin{array}{l}\text { 三島由紀 } \\
\text { 夫 }\end{array}$ \\
\hline
\end{tabular}




\begin{tabular}{|c|c|c|c|c|c|c|c|c|c|}
\hline 81. & Mishima & Yukio & Mar inquieto & $\begin{array}{l}\text { Cia. das } \\
\text { Letras }\end{array}$ & 2002 & $\begin{array}{l}\text { Leiko } \\
\text { Gotoda }^{\mathrm{d}}\end{array}$ & 1954 & 潮騷 & $\begin{array}{l}\text { 三島由紀 } \\
\text { 夫 }\end{array}$ \\
\hline 82. & Mishima & Yukio & $\begin{array}{l}\text { Confissões de } \\
\text { uma máscara }\end{array}$ & $\begin{array}{l}\text { Cia. das } \\
\text { Letras }\end{array}$ & 2004 & $\begin{array}{l}\text { Jaqueline } \\
\text { Nabeta }^{\mathrm{d}}\end{array}$ & 1949 & $\begin{array}{l}\text { 假面の告 } \\
\text { 白 } \\
\text { （仮面の } \\
\text { 告白） }\end{array}$ & $\begin{array}{l}\text { 三島由紀 } \\
\text { 夫 }\end{array}$ \\
\hline 83. & Mishima & Yukio & $\begin{array}{l}\text { O pavilhão } \\
\text { dourado }\end{array}$ & $\begin{array}{l}\text { Cia. das } \\
\text { Letras }\end{array}$ & 2010 & $\begin{array}{l}\text { Shintaro } \\
\text { Hayashi }^{\mathrm{d}}\end{array}$ & 1956 & 金閣寺 & $\begin{array}{l}\text { 三島由紀 } \\
\text { 夫 }\end{array}$ \\
\hline 84. & Mishima & Yukio & $\begin{array}{l}\text { Mar da } \\
\text { Fertilidade }-1 \\
\text { Neve da } \\
\text { primavera }\end{array}$ & Benvirá & 2013 & $\begin{array}{l}\text { Newton } \\
\text { Goldman }{ }^{20}\end{array}$ & 1969 & $\begin{array}{l}\text { 豐饒の海 } \\
\text { (豊饒の } \\
\text { 海) } \\
\text { I. 春の雪 }\end{array}$ & $\begin{array}{l}\text { 三島由紀 } \\
\text { 夫 }\end{array}$ \\
\hline 85. & Mishima & Yukio & $\begin{array}{l}\text { Mar da } \\
\text { Fertilidade }-2 \\
\text { Cavalo } \\
\text { selvagem }\end{array}$ & Benvirá & 2014 & $\begin{array}{l}\text { Isa Mara } \\
\text { Lando }^{20}\end{array}$ & 1969 & $\begin{array}{l}\text { 豐饒の海 } \\
\quad \text { (豊饒の } \\
\text { 海) } \\
\text { II. 奔馬 }\end{array}$ & $\begin{array}{l}\text { 三島由紀 } \\
\text { 夫 }\end{array}$ \\
\hline 86. & Mishima & Yukio & $\begin{array}{l}\text { Mar da } \\
\text { Fertilidade }-3 \\
\text { O templo da } \\
\text { aurora }\end{array}$ & Benvirá & 2014 & $\begin{array}{l}\text { Isa Mara } \\
\text { Lando }^{20}\end{array}$ & 1970 & $\begin{array}{l}\text { 豐饒の海 } \\
\text { (豊饒の } \\
\text { 海) } \\
\text { III. 曉の寺 }\end{array}$ & $\begin{array}{l}\text { 三島由紀 } \\
\text { 夫 }\end{array}$ \\
\hline
\end{tabular}




\begin{tabular}{|c|c|c|c|c|c|c|c|c|c|}
\hline 87. & Mishima & Yukio & $\begin{array}{l}\text { Mar da } \\
\text { Fertilidade }-4 . \\
\text { A queda do } \\
\text { anjo }\end{array}$ & Benvirá & 2015 & $\begin{array}{l}\text { Isa Mara } \\
\text { Lando }^{20}\end{array}$ & 1971 & $\begin{array}{l}\text { 豐饒の海 } \\
\text { (豊饒の } \\
\text { 海) } \\
\text { IV. 天人 } \\
\text { 五衰 }\end{array}$ & $\begin{array}{l}\text { 三島由紀 } \\
\text { 夫 }\end{array}$ \\
\hline 88. & Mishima & Yukio & Patriotismo & Autêntica & 2020 & $\begin{array}{l}\text { Jefferson } \\
\text { José } \\
\text { Teixeira }^{d} \\
\end{array}$ & 1961 & $\begin{array}{l}\text { 憂國（憂 } \\
\text { 国） }\end{array}$ & $\begin{array}{l}\text { 三島由紀 } \\
\text { 夫 }\end{array}$ \\
\hline 89. & Mishima & Yukio & Vida à venda & $\begin{array}{l}\text { Estação } \\
\text { Liberdade }\end{array}$ & 2020 & $\begin{array}{l}\text { Shintaro } \\
\text { Hayashid }^{\mathrm{d}}\end{array}$ & 1968 & $\begin{array}{l}\text { 命売りま } \\
\text { す }\end{array}$ & $\begin{array}{l}\text { 三島由紀 } \\
\text { 夫 }\end{array}$ \\
\hline 90. & Miyazawa & Kenji & $\begin{array}{l}\text { Viagem } \\
\text { noturna no } \\
\text { trem da Via } \\
\text { Láctea }\end{array}$ & Globo & 2008 & $\begin{array}{l}\text { Madalena } \\
\text { Hashimoto; } \\
\text { Lica } \\
\text { Hashimoto }^{\mathrm{d}}\end{array}$ & $\begin{array}{l}1918- \\
1933^{21}\end{array}$ & $\begin{array}{l}\text { 銀河鉄道 } \\
\text { の夜 }\end{array}$ & 宮沢賢治 \\
\hline 91. & Miyazawa & Kenji & O violoncelista & SM & 2009 & $\begin{array}{l}\text { Lúcia } \\
\text { Hiratsuka }^{d}\end{array}$ & 1934 & $\begin{array}{l}\text { セロ弾き } \\
\text { のゴーシ } \\
\text { ユ }\end{array}$ & 宮沢賢治 \\
\hline 92. & Miyazawa & Kenji & $\begin{array}{l}\text { O delegado } \\
\text { que gostava de } \\
\text { usar veneno }\end{array}$ & $\begin{array}{l}\text { Clube de } \\
\text { Autores }\end{array}$ & 2012 & $\begin{array}{l}\text { Gustavo } \\
\text { Hoffman } \\
\text { Moreira }^{22}\end{array}$ & 1986 & $\begin{array}{l}\text { 毒もみの } \\
\text { すきな署 } \\
\text { 長さん }\end{array}$ & 宮沢賢治 \\
\hline
\end{tabular}




\begin{tabular}{|c|c|c|c|c|c|c|c|c|}
\hline 93. Mori & Ogai & $\begin{array}{l}\text { O ganso } \\
\text { selvagem }\end{array}$ & Tessitura & 2010 & $\begin{array}{l}\text { Meiko } \\
\text { Shimon; } \\
\text { Samara } \\
\text { Leonel }^{22}\end{array}$ & 1911-1913 & 雁 & 森鴎外 \\
\hline 94. Mori & Ogai & Vita sexualis & $\begin{array}{l}\text { Estação } \\
\text { Liberdade }\end{array}$ & 2014 & $\begin{array}{l}\text { Fernando } \\
\text { Garcia }^{\mathrm{d}}\end{array}$ & 1909 & $\begin{array}{l}\text { 中タ・セ } \\
\text { クスアリ } \\
\text { ス }\end{array}$ & 森鴎外 \\
\hline 95. Murakami & Haruki & $\begin{array}{l}\text { Caçando } \\
\text { Carneiros }\end{array}$ & $\begin{array}{l}\text { Estação } \\
\text { Liberdade }\end{array}$ & 2001 & $\begin{array}{l}\text { Leiko } \\
\text { Gotoda }^{\mathrm{d}}\end{array}$ & 1982 & $\begin{array}{l}\text { 羊をめぐ } \\
\text { る冒険 }\end{array}$ & 村上春樹 \\
\hline 96. Murakami & Haruki & $\begin{array}{l}\text { Minha querida } \\
\text { Sputnik }\end{array}$ & Objetiva & 2003 & $\begin{array}{l}\text { Ana Luiza } \\
\text { Dantas }\end{array}$ & 1999 & $\begin{array}{l}\text { スプート } \\
\text { ニクの恋 } \\
\text { 人 }\end{array}$ & 村上春樹 \\
\hline 97. Murakami & Haruki & $\begin{array}{l}\text { Dance, dance, } \\
\text { dance }\end{array}$ & $\begin{array}{l}\text { Estação } \\
\text { Liberdade }\end{array}$ & 2005 & $\begin{array}{l}\text { Lica } \\
\text { Hashimoto; } \\
\text { Neide } \\
\text { Nagaed }^{\text {d }} \\
\end{array}$ & 1988 & $\begin{array}{l}\text { ダンス・ } \\
\text { ダンス・ } \\
\text { ダンス }\end{array}$ & 村上春樹 \\
\hline 98. Murakami & Haruki & $\begin{array}{l}\text { Norwegian } \\
\text { Wood }\end{array}$ & Objetiva & 2005 & $\begin{array}{l}\text { Jefferson } \\
\text { José } \\
\text { Teixeirad }^{\text {deix }}\end{array}$ & 1987 & $\begin{array}{l}\text { ノルウェ } \\
\text { イの森 }\end{array}$ & 村上春樹 \\
\hline 99. Murakami & Haruki & $\begin{array}{l}\text { Kafka à beira- } \\
\text { mar }\end{array}$ & Alfaguara & 2008 & $\begin{array}{l}\text { Leiko } \\
\text { Gotoda }^{\mathrm{d}}\end{array}$ & 2002 & $\begin{array}{l}\text { 海辺のカ } \\
\text { フカ }\end{array}$ & 村上春樹 \\
\hline
\end{tabular}




\begin{tabular}{|c|c|c|c|c|c|c|c|c|}
\hline 100. Murakami & Haruki & $\begin{array}{l}\text { Minha querida } \\
\text { Sputnik }\end{array}$ & Alfaguara & 2008 & $\begin{array}{l}\text { Ana Luiza } \\
\text { Dantas }\end{array}$ & 1999 & $\begin{array}{l}\text { スプート } \\
\text { ニクの恋 } \\
\text { 人 }\end{array}$ & 村上春樹 \\
\hline 101. Murakami & Haruki & $\begin{array}{l}\text { Norwegian } \\
\text { Wood }\end{array}$ & Alfaguara & 2008 & $\begin{array}{l}\text { Jefferson } \\
\text { José } \\
\text { Teixeira }^{\text {d }}\end{array}$ & 1987 & $\begin{array}{l}\text { ノルウェ } \\
\text { イの森 }\end{array}$ & 村上春樹 \\
\hline 102. Murakami & Haruki & $\begin{array}{l}\text { Após o } \\
\text { anoitecer }\end{array}$ & Alfaguara & 2009 & $\begin{array}{l}\text { Lica } \\
\text { Hashimoto }^{\mathrm{d}}\end{array}$ & 2004 & $\begin{array}{l}\text { アフター } \\
\text { ダーク }\end{array}$ & 村上春樹 \\
\hline 103. Murakami & Haruki & $\begin{array}{l}\text { 1Q84 } \\
\text { (3 tomos) }\end{array}$ & Alfaguara & $\begin{array}{l}2012- \\
2013\end{array}$ & $\begin{array}{l}\text { Lica } \\
\text { Hashimoto }^{d}\end{array}$ & 2009-2010 & 1Q84 & 村上春樹 \\
\hline 104. Murakami & Haruki & $\begin{array}{l}\text { Caçando } \\
\text { Carneiros }\end{array}$ & Alfaguara & 2014 & $\begin{array}{l}\text { Leiko } \\
\text { Gotoda }\end{array}$ & 1982 & $\begin{array}{l}\text { 羊をめぐ } \\
\text { る冒険 }\end{array}$ & 村上春樹 \\
\hline 105. Murakami & Haruki & $\begin{array}{l}\text { O incolor } \\
\text { Tsukuru } \\
\text { Tazaki e seus } \\
\text { anos de } \\
\text { peregrinação }\end{array}$ & Alfaguara & 2014 & $\begin{array}{l}\text { Eunice } \\
\text { Suenagad }^{\mathrm{d}}\end{array}$ & 2013 & $\begin{array}{l}\text { 色彩を持 } \\
\text { たない多 } \\
\text { 崎つくる } \\
\text { と、彼の } \\
\text { 巡礼の年 }\end{array}$ & 村上春樹 \\
\hline 106. Murakami & Haruki & $\begin{array}{l}\text { Dance, dance, } \\
\text { dance }\end{array}$ & Alfaguara & 2015 & $\begin{array}{l}\text { Lica } \\
\text { Hashimoto; } \\
\text { Neide } \\
\text { Nagae }^{\mathrm{d}}\end{array}$ & 1988 & $\begin{array}{l}\text { ダンス. } \\
\text { ダンス. } \\
\text { ダンス }\end{array}$ & 村上春樹 \\
\hline
\end{tabular}




\begin{tabular}{|c|c|c|c|c|c|c|c|c|}
\hline 107. Murakami & Haruki & $\begin{array}{l}\text { Homens sem } \\
\text { mulheres }\end{array}$ & Alfaguara & 2015 & $\begin{array}{l}\text { Eunice } \\
\text { Suenaga }^{\mathrm{d}}\end{array}$ & 2014 & $\begin{array}{l}\text { 女のいな } \\
\text { い男たち }\end{array}$ & 村上春樹 \\
\hline 108. Murakami & Haruki & Sono $^{23}$ & Alfaguara & 2015 & $\begin{array}{l}\text { Lica } \\
\text { Hashimoto }^{\mathrm{d}}\end{array}$ & 1989 & 眠り & 村上春樹 \\
\hline 109. Murakami & Haruki & $\begin{array}{l}\text { Ouça a canção } \\
\text { do vento \& } \\
\text { Pinball }\end{array}$ & Alfaguara & 2016 & Rita Kohld & 1979/1980 & $\begin{array}{l}\text { 風の歌を } \\
\text { 聴け / } \\
1973 \text { 年の } \\
\text { ピンボー } \\
\text { ル }\end{array}$ & 村上春樹 \\
\hline 110. Murakami & Haruki & $\begin{array}{l}\text { Crônica do } \\
\text { pássaro de } \\
\text { corda }\end{array}$ & Alfaguara & 2017 & $\begin{array}{l}\text { Eunice } \\
\text { Suenagad }^{\mathrm{d}}\end{array}$ & 1994-1995 & $\begin{array}{l}\text { ねじまき } \\
\text { 鳥クロニ } \\
\text { クル }\end{array}$ & 村上春樹 \\
\hline 111. Murakami & Haruki & $\begin{array}{l}\text { O assassinato } \\
\text { do } \\
\text { comendador ( } 2 \\
\text { volumes) }\end{array}$ & Alfaguara & $\begin{array}{l}2018- \\
2020\end{array}$ & Rita Kohld & 2017 & $\begin{array}{l}\text { 騎士団長 } \\
\text { 殺し }\end{array}$ & 村上春樹 \\
\hline 112. Murakami & Haruki & $\begin{array}{l}\text { O elefante } \\
\text { desaparece }\end{array}$ & Alfaguara & 2018 & $\begin{array}{l}\text { Lica } \\
\text { Hashimoto }^{\mathrm{d}}\end{array}$ & $1993 / 2005^{24}$ & 象の消滅 & 村上春樹 \\
\hline 113. Murakami & Ryu & $\begin{array}{l}\text { Azul quase } \\
\text { transparente }\end{array}$ & Brasiliense & 1986 & $\begin{array}{l}\text { Paulo } \\
\text { Henriques } \\
\text { Britto }^{\mathrm{i}}\end{array}$ & 1976 & $\begin{array}{l}\text { 限りなく } \\
\text { 透明に近 } \\
\text { いブルー }\end{array}$ & 村上龍 \\
\hline
\end{tabular}




\begin{tabular}{|c|c|c|c|c|c|c|c|c|}
\hline 114. Murakami & Ryu & Miso soup & $\begin{array}{l}\text { Cia. das } \\
\text { Letras }\end{array}$ & 2005 & $\begin{array}{l}\text { Jefferson } \\
\text { José } \\
\text { Teixeira }^{d} \\
\end{array}$ & 1997 & $\begin{array}{l}\text { インザ · } \\
\text { ミソスー } \\
\text { プ }\end{array}$ & 村上龍 \\
\hline 115. Murata & Sayaka & $\begin{array}{l}\text { Querida } \\
\text { konbini }\end{array}$ & $\begin{array}{l}\text { Estação } \\
\text { Liberdade }\end{array}$ & 2018 & Rita Kohld & 2016 & $\begin{array}{l}\text { コンビニ } \\
\text { 人間 }\end{array}$ & $\begin{array}{l}\text { 村田沙耶 } \\
\text { 香 }\end{array}$ \\
\hline 116. Nagai & Kafu & $\begin{array}{l}\text { Crônica da } \\
\text { estação das } \\
\text { chuvas }\end{array}$ & $\begin{array}{l}\text { Estação } \\
\text { Liberdade }\end{array}$ & 2008 & $\begin{array}{l}\text { Dirce } \\
\text { Miyamura }^{\mathrm{d}}\end{array}$ & 1931 & $\begin{array}{l}\text { つゆのあ } \\
\text { とさき }\end{array}$ & 永井荷風 \\
\hline 117. Nagai & Kafu & $\begin{array}{l}\text { Histórias da } \\
\text { outra margem }\end{array}$ & $\begin{array}{l}\text { Estação } \\
\text { Liberdade }\end{array}$ & 2013 & $\begin{array}{l}\text { Andrei } \\
\text { Cunha }^{\mathrm{d}}\end{array}$ & 1937 & 濹東綺譚 & 永井荷風 \\
\hline 118. Nagai & Kafu & $\begin{array}{l}\text { Guerra de } \\
\text { gueixas }\end{array}$ & $\begin{array}{l}\text { Estação } \\
\text { Liberdade }\end{array}$ & 2016 & $\begin{array}{l}\text { Andrei } \\
\text { Cunha }^{d}\end{array}$ & 1918 & 腕くらべ & 永井荷風 \\
\hline 119. Nagayo & Yoshio & $\begin{array}{l}\text { A imagem de } \\
\text { bronze: } \\
\text { romance }\end{array}$ & $\begin{array}{l}\text { Irmãos } \\
\text { Pongetti }{ }^{25}\end{array}$ & 1941 & $\begin{array}{l}\text { Zenaide } \\
\text { Andrea }\end{array}$ & 1923 & $\begin{array}{l}\text { 青銅の基 } \\
\text { 督 }\end{array}$ & 長与善郎 \\
\hline 120. Natsuki & Shizuko & $\begin{array}{l}\text { Assassinato no } \\
\text { Monte Fuji }\end{array}$ & Brasiliense & 1989 & $\begin{array}{l}\text { Sonia } \\
\text { Goldfeder }\end{array}$ & 1982 & W の悲劇 & 夏樹静子 \\
\hline 121. Natsume & Soseki & $\begin{array}{l}\text { Sonhos de dez } \\
\text { noites }\end{array}$ & $\mathrm{ACBJ}$ & 1996 & $\begin{array}{l}\text { Antônio } \\
\text { Nojiriid }^{\mathrm{d}}\end{array}$ & 1908 & 夢十夜 & 夏目漱石 \\
\hline
\end{tabular}




\begin{tabular}{|c|c|c|c|c|c|c|c|c|}
\hline 122. Natsume & Soseki & Coração & Globo & 2008 & Junko Ota ${ }^{d}$ & 1914 & こころ & 夏目漱石 \\
\hline 123. Natsume & Soseki & $\begin{array}{l}\text { Eu sou um } \\
\text { gato }\end{array}$ & $\begin{array}{l}\text { Estação } \\
\text { Liberdade }\end{array}$ & 2008 & $\begin{array}{l}\text { Jefferson } \\
\text { José } \\
\text { Teixeira }^{\mathrm{d}}\end{array}$ & 1905 & $\begin{array}{l}\text { 吾輩は猫 } \\
\text { である }\end{array}$ & 夏目漱石 \\
\hline 124. Natsume & Soseki & E depois & $\begin{array}{l}\text { Estação } \\
\text { Liberdade }\end{array}$ & 2011 & $\begin{array}{l}\text { Lica } \\
\text { Hashimoto }^{\mathrm{d}}\end{array}$ & 1909 & それから & 夏目漱石 \\
\hline 125. Natsume & Soseki & Sanshiro & $\begin{array}{l}\text { Estação } \\
\text { Liberdade }\end{array}$ & 2013 & $\begin{array}{l}\text { Fernando } \\
\text { Garcia }^{d}\end{array}$ & 1908 & 三四郎 & 夏目漱石 \\
\hline 126. Natsume & Soseki & O portal & $\begin{array}{l}\text { Estação } \\
\text { Liberdade }\end{array}$ & 2014 & $\begin{array}{l}\text { Fernando } \\
\text { Garcia }^{d}\end{array}$ & 1910 & 門 & 夏目漱石 \\
\hline 127. Natsume & Soseki & Botchan & $\begin{array}{l}\text { Estação } \\
\text { Liberdade }\end{array}$ & 2016 & $\begin{array}{l}\text { Jefferson } \\
\text { José } \\
\text { Teixeira }^{d}\end{array}$ & 1906 & $\begin{array}{l}\text { 坊っちや } \\
\text { ん }\end{array}$ & 夏目漱石 \\
\hline 128. Oe & Kenzaburo & $\begin{array}{l}\text { O grito } \\
\text { silencioso }\end{array}$ & $\begin{array}{l}\text { Francisco } \\
\text { Alves }\end{array}$ & 1983 & Sérgio Ryff & 1967 & $\begin{array}{l}\text { 万延元年 } \\
\text { のフット } \\
\text { ボール }\end{array}$ & $\begin{array}{l}\text { 大江健三 } \\
\text { 郎 }\end{array}$ \\
\hline 129. Oe & Kenzaburo & $\begin{array}{l}\text { O grito } \\
\text { silencioso }\end{array}$ & $\begin{array}{l}\text { Abril } \\
\text { Cultural }\end{array}$ & 1986 & Sérgio Ryff & 1967 & $\begin{array}{l}\text { 万延元年 } \\
\text { のフット } \\
\text { ボール }\end{array}$ & $\begin{array}{l}\text { 大江健三 } \\
\text { 郎 }\end{array}$ \\
\hline
\end{tabular}




\begin{tabular}{|c|c|c|c|c|c|c|c|c|}
\hline 130. Oe & Kenzaburo & $\begin{array}{l}\text { Contos de } \\
\text { Kenzaburo Oe }\end{array}$ & $\begin{array}{l}\text { Centro de } \\
\text { Estudos } \\
\text { Japoneses } \\
\text { da USP } \\
\end{array}$ & 1995 & $* 26$ & - & - & $\begin{array}{l}\text { 大江健三 } \\
\text { 郎 }\end{array}$ \\
\hline 131. Oe & Kenzaburo & $\begin{array}{l}\text { Uma questão } \\
\text { pessoal }\end{array}$ & $\begin{array}{l}\text { Cia. das } \\
\text { Letras }\end{array}$ & 2003 & $\begin{array}{l}\text { Leiko } \\
\text { Gotoda }^{\mathrm{d}}\end{array}$ & 1964 & $\begin{array}{l}\text { 個人的な } \\
\text { 体験 }\end{array}$ & $\begin{array}{l}\text { 大江健三 } \\
\text { 郎 }\end{array}$ \\
\hline 132. Oe & Kenzaburo & $\begin{array}{l}\text { Jovens de um } \\
\text { novo tempo, } \\
\text { despertai! }\end{array}$ & $\begin{array}{l}\text { Cia. das } \\
\text { Letras }\end{array}$ & 2006 & $\begin{array}{l}\text { Leiko } \\
\text { Gotoda }^{\mathrm{d}}\end{array}$ & 1983 & $\begin{array}{l}\text { 新しい人 } \\
\text { よ眼ざめ } \\
\text { よ } \\
\end{array}$ & $\begin{array}{l}\text { 大江健三 } \\
\text { 郎 }\end{array}$ \\
\hline 133. Oe & Kenzaburo & $\begin{array}{l}14 \text { contos de } \\
\text { Kenzaburo Oe }\end{array}$ & $\begin{array}{l}\text { Cia. das } \\
\text { Letras }\end{array}$ & 2011 & $\begin{array}{l}\text { Leiko } \\
\text { Gotoda }^{\mathrm{d}}\end{array}$ & - & - & $\begin{array}{l}\text { 大江健三 } \\
\text { 郎 }\end{array}$ \\
\hline 134. Ogawa & Yoko & Hotel Íris & Leya & 2011 & $\begin{array}{l}\text { Marly } \\
\text { Peres }^{27}\end{array}$ & 1996 & $\begin{array}{l}\text { ホテル } \\
\text { アイリス }\end{array}$ & 小川 洋子 \\
\hline 135. Ogawa & Yoko & $\begin{array}{l}\text { O museu do } \\
\text { silêncio }\end{array}$ & $\begin{array}{l}\text { Estação } \\
\text { Liberdade }\end{array}$ & 2016 & Rita Kohld & 2000 & $\begin{array}{l}\text { 沈黙博物 } \\
\text { 館 }\end{array}$ & 小川洋子 \\
\hline 136. Ogawa & Yoko & $\begin{array}{l}\text { A fórmula } \\
\text { preferida do } \\
\text { professor }\end{array}$ & $\begin{array}{l}\text { Estação das } \\
\text { Letras }\end{array}$ & 2017 & $\begin{array}{l}\text { Shintaro } \\
\text { Hayashi }^{\mathrm{d}}\end{array}$ & 2003 & $\begin{array}{l}\text { 博士の愛 } \\
\text { した数式 }\end{array}$ & 小川洋子 \\
\hline
\end{tabular}




\begin{tabular}{|c|c|c|c|c|c|c|c|c|}
\hline 137. Shiga & Naoya & $\begin{array}{l}\text { Trajetória em } \\
\text { noite escura }\end{array}$ & Ateliê & 2011 & $\begin{array}{l}\text { Neide } \\
\text { Nagaed }^{\mathrm{d}}\end{array}$ & 1921-1937 & 暗夜行路 & 志賀直哉 \\
\hline 138. Shônagon & Sei & $\begin{array}{l}\text { O livro do } \\
\text { travesseiro }\end{array}$ & 34 & 2013 & $* 28$ & $1001 ?$ & 枕草子 & 清少納言 \\
\hline 139. Takahashi & Gen'ichiro $^{29}$ & $\begin{array}{l}\text { Sayonara, } \\
\text { Gângsters }\end{array}$ & Ediouro & 2006 & $\begin{array}{l}\text { Jefferson } \\
\text { José } \\
\text { Teixeira }^{d}\end{array}$ & 1982 & 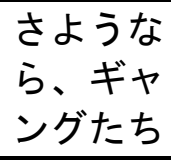 & $\begin{array}{l}\text { 高橋源一 } \\
\text { 郎 }\end{array}$ \\
\hline 140. Tanizaki & Jun'ichiro $^{30}$ & Naomi & Brasiliense & 1986 & $\begin{array}{l}\text { Sônia } \\
\text { Coutinho }\end{array}$ & 1924 & 痴人の愛 & $\begin{array}{l}\text { 谷崎潤一 } \\
\text { 郎 }\end{array}$ \\
\hline 141. Tanizaki & Jun'ichiro & A chave & $\begin{array}{l}\text { Cia. das } \\
\text { Letras }\end{array}$ & 2000 & $\begin{array}{l}\text { Jefferson } \\
\text { José } \\
\text { Teixeirad }^{d}\end{array}$ & 1956 & 鍵 & $\begin{array}{l}\text { 谷崎潤一 } \\
\text { 郎 }\end{array}$ \\
\hline 142. Tanizaki & Jun'ichiro & Voragem & $\begin{array}{l}\text { Cia. das } \\
\text { Letras }\end{array}$ & 2001 & $\begin{array}{l}\text { Leiko } \\
\text { Gotoda }^{\mathrm{d}}\end{array}$ & $1928-1930$ & せ & $\begin{array}{l}\text { 谷崎潤一 } \\
\text { 郎 }\end{array}$ \\
\hline 143. Tanizaki & Jun'ichiro & $\begin{array}{l}\text { Diário de um } \\
\text { velho louco }\end{array}$ & $\begin{array}{l}\text { Estação } \\
\text { Liberdade }\end{array}$ & 2002 & $\begin{array}{l}\text { Leiko } \\
\text { Gotoda }^{\mathrm{d}}\end{array}$ & 1961 & $\begin{array}{l}\text { 瘋頡老人 } \\
\text { 日記 }\end{array}$ & $\begin{array}{l}\text { 谷崎潤一 } \\
\text { 郎 }\end{array}$ \\
\hline 144. Tanizaki & Jun'ichiro & $\begin{array}{l}\text { Há quem } \\
\text { prefira urtigas }\end{array}$ & $\begin{array}{l}\text { Cia. das } \\
\text { Letras }\end{array}$ & 2003 & $\begin{array}{l}\text { Leiko } \\
\text { Gotoda }^{\mathrm{d}}\end{array}$ & 1929 & 蓼喰う蝁 & $\begin{array}{l}\text { 谷崎潤一 } \\
\text { 郎 }\end{array}$ \\
\hline
\end{tabular}




\begin{tabular}{|c|c|c|c|c|c|c|c|c|}
\hline 145. Tanizaki & Jun'ichiro & Voragem & $\begin{array}{l}\text { Planeta } \\
\text { deAgostini; } \\
\text { Cia. das } \\
\text { Letras }\end{array}$ & 2003 & $\begin{array}{l}\text { Leiko } \\
\text { Gotodad }^{\mathrm{d}}\end{array}$ & $1928-1930$ & 凹 & $\begin{array}{l}\text { 谷崎潤一 } \\
\text { 郎 }\end{array}$ \\
\hline 146. Tanizaki & Jun'ichiro & $\begin{array}{l}\text { Amor } \\
\text { insensato }\end{array}$ & $\begin{array}{l}\text { Cia. das } \\
\text { Letras }\end{array}$ & 2004 & $\begin{array}{l}\text { Jefferson } \\
\text { José } \\
\text { Teixeira }^{\mathrm{d}} \\
\end{array}$ & 1924 & 痴人の愛 & $\begin{array}{l}\text { 谷崎潤一 } \\
\text { 郎 }\end{array}$ \\
\hline 147. Tanizaki & Jun'ichiro & $\begin{array}{l}\text { As irmãs } \\
\text { Makioka }\end{array}$ & $\begin{array}{l}\text { Estação } \\
\text { Liberdade }\end{array}$ & 2005 & $* 31$ & $\begin{array}{l}1943- \\
1948\end{array}$ & 細雪 & $\begin{array}{l}\text { 谷崎潤一 } \\
\text { 郎 }\end{array}$ \\
\hline 148. Tanizaki & Jun'ichiro & $\begin{array}{l}\text { A vida secreta } \\
\text { do senhor de } \\
\text { Musashi }\end{array}$ & $\begin{array}{l}\text { Cia. das } \\
\text { Letras }\end{array}$ & 2009 & $\begin{array}{l}\text { Dirce } \\
\text { Miyamura }^{\mathrm{d}}\end{array}$ & 1935 & $\begin{array}{l}\text { 武州公秘 } \\
\text { 話 }\end{array}$ & $\begin{array}{l}\text { 谷崎潤一 } \\
\text { 郎 }\end{array}$ \\
\hline 149. Tanizaki & Jun'ichiro & $\begin{array}{l}\text { A gata, um } \\
\text { homem e duas } \\
\text { mulheres / } \\
\text { O cortador de } \\
\text { juncos }\end{array}$ & $\begin{array}{l}\text { Estação } \\
\text { Liberdade }\end{array}$ & 2016 & $* 32$ & 1936 / 1932 & $\begin{array}{l}\text { 猫と庄造 } \\
\text { と二人の } \\
\text { 女/蘆刚 }\end{array}$ & $\begin{array}{l}\text { 谷崎潤一 } \\
\text { 郎 }\end{array}$ \\
\hline 150. Tanizaki & Jun'ichiro & Voragem & $\begin{array}{l}\text { Tag; Cia. } \\
\text { das Letras }\end{array}$ & 2018 & $\begin{array}{l}\text { Leiko } \\
\text { Gotoda }^{\mathrm{d}}\end{array}$ & $1928-1930$ & 円 & $\begin{array}{l}\text { 谷崎潤一 } \\
\text { 郎 }\end{array}$ \\
\hline
\end{tabular}




\begin{tabular}{|c|c|c|c|c|c|c|c|c|}
\hline 151. Tanizaki & Jun'ichiro & $\begin{array}{l}\text { A ponte } \\
\text { flutuante dos } \\
\text { sonhos / } \\
\text { Retrato de } \\
\text { Shunkin } \\
\end{array}$ & $\begin{array}{l}\text { Estação } \\
\text { Liberdade }\end{array}$ & 2019 & $\begin{array}{l}\text { Andrei } \\
\text { Cunha; } \\
\text { Ariel } \\
\text { Oliveira; } \\
\text { Lídia Ivasa }^{\mathrm{d}}\end{array}$ & 1959 / 1933 & $\begin{array}{l}\text { 夢の浮橋 } \\
\text { /春琴抄 }\end{array}$ & $\begin{array}{l}\text { 谷崎潤一 } \\
\text { 郎 }\end{array}$ \\
\hline 152. Tawada & Yoko & $\begin{array}{l}\text { Memórias de } \\
\text { um urso-polar }\end{array}$ & Todavia & 2019 & $\begin{array}{l}\text { Lucia } \\
\text { Collischonn } \\
\text { de Abreu; } \\
\text { Gerson } \\
\text { Roberto } \\
\text { Neumann }{ }^{33} \\
\end{array}$ & 2011 & $\begin{array}{l}\text { 雪の練習 } \\
\text { 生 }\end{array}$ & $\begin{array}{l}\text { 多和田 葉 } \\
\text { 子 }\end{array}$ \\
\hline 153. Tokunaga & $\begin{array}{l}\text { Naoshi } \\
\text { (Sunao) }^{34}\end{array}$ & Rua sem sol & Brasiliense & 1945 & $\begin{array}{l}\text { Jorge } \\
\text { Amado }^{35}\end{array}$ & 1929 & $\begin{array}{l}\text { 太陽のな } \\
\text { い街 }\end{array}$ & 徳永直 \\
\hline 154. Ueda & Akinari & $\begin{array}{l}\text { Contos da } \\
\text { chuva e da lua }\end{array}$ & $\begin{array}{l}\text { Centro de } \\
\text { Estudos } \\
\text { Japoneses } \\
\text { da USP } \\
\end{array}$ & 1996 & $* 36$ & $1776 ?$ & 雨月物語 & 上田秋成 \\
\hline 155. Yoshikawa & Eiji & $\begin{array}{l}\text { Musashi } \\
\text { (2 tomos) }\end{array}$ & $\begin{array}{l}\text { Estação } \\
\text { Liberdade }\end{array}$ & 1999 & $\begin{array}{l}\text { Leiko } \\
\text { Gotoda }^{\mathrm{d}}\end{array}$ & 1939 & 宮本武蔵 & 吉川英治 \\
\hline 156. Yoshikawa & Eiji & $\begin{array}{l}\text { Musashi } \\
\text { (3 tomos) }\end{array}$ & $\begin{array}{l}\text { Estação } \\
\text { Liberdade }\end{array}$ & 2009 & $\begin{array}{l}\text { Leiko } \\
\text { Gotoda }^{\mathrm{d}}\end{array}$ & 1939 & 宮本武蔵 & 吉川英治 \\
\hline
\end{tabular}




\begin{tabular}{|c|c|c|c|c|c|c|c|c|}
\hline 157. Yoshimoto & Banana & Kitchen & $\begin{array}{l}\text { Nova } \\
\text { Fronteira }\end{array}$ & 1995 & $\begin{array}{l}\text { Julieta } \\
\text { Leite }^{37}\end{array}$ & 1988 & キッチン & $\begin{array}{l}\text { 吉本ばな } \\
\text { な }\end{array}$ \\
\hline 158. Yoshimoto & Banana & Tsugumi & $\begin{array}{l}\text { Estação } \\
\text { Liberdade }\end{array}$ & 2015 & $\begin{array}{l}\text { Lica } \\
\text { Hashimoto }^{d}\end{array}$ & 1989 & TUGUMI & $\begin{array}{l}\text { 吉本ばな } \\
\text { な }\end{array}$ \\
\hline 159. Yoshimura & Akira & Naufrágios & Best Seller & 2003 & $\begin{array}{l}\text { Sylvio } \\
\text { Monteiro } \\
\text { Deutsch } \\
\end{array}$ & 1982 & 破船 & 吉村昭 \\
\hline 160. Yoshiyuki & Junnosuke & $\begin{array}{l}\text { O quarto } \\
\text { escuro }\end{array}$ & Brasiliense & 1988 & $\begin{array}{l}\text { Fernando } \\
\text { Vugman }\end{array}$ & 1970 & 暗室 & $\begin{array}{l}\text { 吉行淳之 } \\
\text { 介 }\end{array}$ \\
\hline 161. Yumoto & Kazumi & Os amigos & $\begin{array}{l}\text { Martins } \\
\text { Fontes }\end{array}$ & 2000 & $\begin{array}{l}\text { Lica } \\
\text { Hashimoto }^{\mathrm{d}}\end{array}$ & 1992 & 夏の庭 & $\begin{array}{l}\text { 湯本香樹 } \\
\text { 実 }\end{array}$ \\
\hline 162. Yumoto & Kazumi & $\begin{array}{l}\text { O outono do } \\
\text { Álamo }\end{array}$ & $\begin{array}{l}\text { Martins } \\
\text { Fontes }\end{array}$ & 2000 & $\begin{array}{l}\text { Lica } \\
\text { Hashimoto }^{d}\end{array}$ & 1997 & $\begin{array}{l}\text { ポプラの } \\
\text { 秋 }\end{array}$ & $\begin{array}{l}\text { 湯本香樹 } \\
\text { 実 }\end{array}$ \\
\hline 163. Yumoto & Kazumi & $\begin{array}{l}\text { O urso e o } \\
\text { gato-montês }\end{array}$ & Outono & 2012 & $\begin{array}{l}\text { Jefferson } \\
\text { Teixeira }^{\mathrm{d}}\end{array}$ & 2008 & $\begin{array}{l}\text { くまとや } \\
\text { まねこ }\end{array}$ & $\begin{array}{l}\text { 湯本香樹 } \\
\text { 実 }\end{array}$ \\
\hline
\end{tabular}


Quadro 2: Coletâneas de contos organizada por ordem alfabética do sobrenome do primeiro autor ou organizador. O " $\mathrm{d}$ " e o " $\mathrm{i}$ " sobrescritos ao lado do nome do(s) tradutor(es) indicam se a tradução foi direta ou indireta, nos casos em que essa informação é sabida.

\section{N. Referência}

ARIYOSHI et al. O canto da terra: antologia do canto contemporâneo japonês. Porto Alegre: Movimento; Fundação

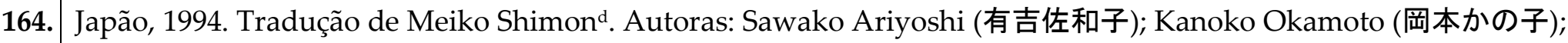
Minako Ohba (大庭みな子); Yumiko Kurahashi (倉橋由美子).

NAGAE, Neide Hissae (Org.). Momotarô: traduções e percursos no exercício de tradução japonês-português. São Paulo: FFLCH / USP, 2018. Traduções do conto de Akutagawad: André Felipe de Sousa Almeida; José Maurício de Faria Yoshitake; Lídia Harumi Ivasa; Pérola Isis da Silva Bitencourt; Thiago Cosme de Abreu. Tradução da versão sem 165. autoriad: Cristine Akemi Sakô. Tradução da cantiga: Vanessa Higashi. Inclui o conto de Akutagawa Ryunosuke e cinco traduções diferentes do mesmo; prefácio de Kyoko Sekino; apresentação de Neide Nagae e Lica Hashimoto; uma versão da história baseada em textos tradicionais infantis; tradução de música infantil sobre Momotarô; ensaio sobre o conto de Akutagawa e a biografia deste.

NAGAE, Neide Hissae; NAKAEMA, Olivia Yumi (Orgs.). Konjaku Monogatarishu [今昔物語集]: narrativas antigas do Japão. São Paulo: FFLCH / USP, 2018. Tradutores': Lídia Ivasa; Cristine Akemi Sako; Kumie Fujimori; Roberto

166. Satoshi Numada; Luciana Miho Kawasaki; Luiza Nana Yoshida; Thalita Yuri Yuhara; Vinícius Ito Ramos; Fernando Carlos Chamas; Luís Guilherme Libaneo de Camargo; Lucas Damasceno Endo; Thiago Cosme de Abreu; Olivia Yumi Nakaema; Shirlei Lica Ichisato Hashimoto; Luiz Henrique Bozzo Moreira. 
NOJIRI, Antônio (Sel.). Maravilhas do conto japonês. São Paulo: Cultrix, 1962. Tradutores ${ }^{\mathrm{d} / i}$ : Albertino Pinheiro Jr.; Antônio Nojiri; Fuyou Koyama; Henrique Santo; José Yamashiro; Katsunori Wakisaka; Konoske Oseki; Shinobu Saiki; Teiiti Suzuki; Yoshihiro Watanabe. Autores: Murasaki Shikibu (紫式部); Saikaku Ibara (井原西鶴); Doppo Kunikida (国木田獨歩); Sôseki Natsume (夏目漱石); Naoya Shiga (志賀直哉); Jun'ichiro Tanizaki (谷崎潤一郎); Kan Kikuchi (菊 池寛); Masuji Ibuse (井伏鱒二); Yasunari Kawabata (川端康成); Riichi Yokomitsu (横光利一); Ango Sakaguchi (坂口安 吾); Osamu Dazai (太宰治); Sakunosuke Oda (織田作之助); Yasushi Inoue (井上靖); Saisei Murou (室生犘星). O livro inclui ainda textos de autoria incerta retirados das seguintes obras: Narrativas de Uji Shui (宇治拾遺物語); Narrativas de Yamato (大和物語); Narrativas de Ise (伊勢物語); Narrativas de Outras Eras (今昔物語集); Narrativas de Tsutsumi Tchunagon (堤中納言物語), esta última na transliteração aportuguesada de Nojiri. A transliteração Hepburn seria Tsutsumi “Chunagon”.

168.

NOJIRI, Antônio (Org.). Contos japoneses. Rio de Janeiro: Ediouro, 1966. Reedição do volume acima, Maravilhas do conto japonês, com ilustrações de José Rivelli Neto e breve nota introdutória, sem autoria assinalada.

WAKISAKA, Geny (Org.). Contos da Era Meiji. São Paulo: Centro de Estudos Japoneses da USP, 1993. Tradutores ${ }^{\text {d: }}$ 169. Margarete Mitico Takehara; Tae Suzuki; Emi Sato; Luís Fábio Mietto; Geny Wakisaka; Rosane Lie Ikeda. Autores: Ichiyô Higuchi (樋口一葉); Kyoka Izumi (泉鏡花); Doppo Kunikida (国木田独歩); Sôseki Natsume (夏目漱石); Katai Tayama (田山花袋); Ogai Mori (森鴎外). 
WAKISAKA, Geny (Org.). Contos modernos japoneses. São Paulo: Centro de Estudos Japoneses da USP, 1994.

170.

Tradutores $^{d}$ : Geny Wakisaka; Emi Sato; Mayumi Edna Iko; Luís Fábio Mietto; Valdinei Dias Batista; Rosane Lie Ikeda; Lídia Masumi Fukasawa; Tae Suzuki. Autores: Shûsei Tokuda (徳田秋声); Tôson Shimazaki (島崎藤村); Ogai Mori (森 鴎外); Ryunosuke Akutagawa (芥川龍之介); Takeo Arishima (有島武郎).

YAMASHIRO, José (Org.). Árvores irmãs: contos japoneses. São Paulo: Clube do Livro, 1958. Tradutores ${ }^{\text {d/i: }}$ José

171.

Yamashiro; Nelson Coelho. Autores: Kaijin Akashi (明石海人); Fumiko Hayashi (林芙美子); Ryunosuke Akutagawa (芥川龍之介); Yasunari Kawabata (川端康成); Fumio Niwa (丹羽文雄); Riichi Yokomitsu (横光利一); Kazuo Ozaki (尾 崎一雄).

${ }^{1}$ A transliteração Hepburn, a mais utilizada internacionalmente, foi escolhida para padronização na lista. Na publicação mais antiga consta como "Ryunossuke" - uma transliteração aportuguesada do tradutor Antônio Nojiri.

${ }^{2}$ Conforme orientação da ABNT, assim indicamos a falta de década certa, embora suponhamos que esta tenha ocorrido no máximo dez anos antes ou depois da edição de Rashomon... de 1981, cujo miolo é absolutamente igual.

${ }^{3}$ A título de referência, indica-se o intervalo em que o autor publicou seus contos em periódicos japoneses. Não houve compilação publicada em vida.

${ }^{4}$ Contém ilustrações de Hokusai Katsushika (葛飾北斎).

${ }^{5}$ Ilustrado por Hideyuki Fujiwara.

${ }^{6}$ Reedição revisada da tradução anteriormente publicada pela Editora Paulicéia, em 1992.

7 Problema idêntico ao do livro da Nota 2, acima, em relação à edição de Pôr do Sol de 1981.

$82^{\mathrm{a}}$ ed. com prefácio de Martin Scorsese.

${ }^{9}$ Edição produzida a partir da tradução de Geraldine Harcourt para o inglês. 
10 Tradução direta: Maria Fusako Tomimatsu; Monica Setuyo Okamoto; Takao Namekata. Revisão de Márcia Hitomi Takahashi.

11 Embora o tradutor seja português, o texto foi adaptado para o português brasileiro.

$122^{\mathrm{a}}$ ed. revisada e com prefácio de Teixeira de Carvalho.

$133^{\mathrm{a}}$ ed. com adição de posfácio de Roberto Kazuo Yokota.

${ }^{14}$ Grafia original, pré-reforma ortográfica. A grafia atual - nesta e em outras obras - foi indicada entre parênteses.

15 Tradutoras: Gilda Stuart (Tomo I); Maiza Martins de Siqueira; Renata Brant de Carvalho (Tomo II)

${ }^{16}$ A autora japonesa publicou este livro originalmente em inglês, o qual foi, posteriormente, traduzido para o japonês por Ishizu Chihiro.

${ }^{17}$ Na primeira obra deste autor traduzida para o Brasil, utilizou-se a transliteração Hepburn, "Seicho Matsumoto". Na segunda, utilizou-se "Seityo Matumoto", que é a transliteração padrão adotada pelo governo japonês. Destarte, indicam-se aqui as duas na listagem para evitar dissociação.

18 Tradução direta. Revisão de Paulo Arinos. Prefácio de Evangelista Prado. Ilustrações de Vicente di Grado.

${ }^{19}$ Data certa desconhecida, porém 1977-1986 é o intervalo provável em que a obra foi publicada no Brasil, conforme minha investigação somada às observações de Kato, em “Edições brasileiras de ficção japonesa” (2006).

${ }^{20}$ A Benvirá fez revisão das traduções originais da Brasiliense por Naomi Hoki Moniz e Yuko Tomita Koch (v. 1) e Meiko Shimon (v. 2, 3 e $4)$.

${ }^{21}$ Intervalo de escrita original dos contos, muitos dos quais não foram publicados em vida. “O violoncelista”, por exemplo, saiu postumamente em 1934.

22 Tradução direta. Edição bilíngue.

${ }^{23}$ Ilustrado por Kat Menschik. Conto incluído também na coletânea $\mathbf{O}$ elefante desaparece.

24 Seleção de contos lançada primeiro em inglês, nos EUA, em 1993, e depois no Japão, em 2005. A tradução brasileira é direta do japonês.

${ }^{25}$ Capa original de Riokai Ohashi e ilustrações de Tsusei Konô. Prefácio de Cláudio de Souza.

${ }^{26}$ Tradução (direta): Nana Luiza Yoshida; Geny Wakisaka; Tae Suzuki; Luís Fábio Mietto; Junko Ota; Lídia Masumi Fukasawa; Neide

Nagae.

27 Traduzido do francês.

28 Tradução (direta): Geny Wakisaka; Junko Ota; Lica Hashimoto; Luiza Nana Yoshida; Madalena Hashimoto Cordaro

${ }^{29} \mathrm{Na}$ capa, a grafia do nome do autor não contém o apóstrofo indicando a divisão silábica correta (importante para a correta pronunciação). 
${ }^{30}$ Nas capas de alguns livros, a grafia do nome do autor não contém o apóstrofo indicando a divisão silábica correta (importante para a correta pronunciação). Optou-se por padronizar a grafia na listagem com este apóstrofo.

31 Tradução (direta): Leiko Gotoda, Neide Nagae, Eliza Atsuko Tashiro e Kanami Hirai.

32 Tradução (direta): Andrei Cunha, Clicie Araujo, Lidia Ivasa, Maria Luisa Vanik Pinto e Tomoko Gaudioso

33 Traduzido a partir da versão alemã, feita pela própria autora, intitulada Etüden im Schnee.

34 A leitura correta do nome do autor é "Sunao", porém foi erroneamente indicada na capa do livro como "Naoshi".

35 Segundo Denise Bottmann, a tradução foi falsamente atribuída (cf. Jorge Amado "tradutor", naogostodeplagio.blogspot.com/2014/11/jorge-amado-tradutor.html).

36 Tradução (direta): Geny Wakisaka; Neide Hisae Nagae; Kanami Hirai; Luís Fábio Mietto; Luiza Nana Yoshida; Tae Suzuki; Elisa Mie

Nishiko.

37 Tradução a partir do italiano de Giorgio Amitrano, cotejando o inglês de Mergan Barkus.

${ }^{38}$ Ilustrado por Komako Sakai. 